\title{
Spanish Bentonites: A Review and New Data on Their Geology, Mineralogy, and Crystal Chemistry
}

\author{
Emilia García-Romero ${ }^{1,2, *}$, Eva María Manchado ${ }^{3}$, Mercedes Suárez ${ }^{3}$ (ib and \\ Javier García-Rivas 4 (D) \\ 1 Department of Mineralogy and Petrology, Complutense University of Madrid, 28040 Madrid, Spain \\ 2 Geosciences Institute (IGEO) Spanish Research Council and Complutense University (CSIC-UCM), \\ 28040 Madrid, Spain \\ 3 Department of Geology, University of Salamanca, 37008 Salamanca, Spain; a87578@usal.es (E.M.M.); \\ msuarez@usal.es (M.S.) \\ 4 Center for Nuclear Sciences and Technologies (C2TN), Instituto Superior Técnico, University of Lisbon, \\ 2695-066 Bobadela-LRS, Portugal; javier.rivas@ctn.tecnico.ulisboa.pt \\ * Correspondence: mromero@ucm.es
}

Received: 3 October 2019; Accepted: 5 November 2019; Published: 11 November 2019

\begin{abstract}
A review and a synthesis of the geological, mineralogical, and crystal chemical data available in the literature on active Spanish bentonitic exploitations were done, and at the same time, new data are provided from a set of representative samples from these deposits. They were located in three different areas with different geological origins: (1) Miocene sedimentary deposits from the Tajo Basin (Madrid-Toledo provinces) in the center of the Iberian Peninsula, where bentonites appear in two different units named for their colors (Green Clays and Pink Clays); (2) samples from Tamame de Sayago (Zamora province) originating from the hydrothermal alteration of granitic Variscan rocks; and 3) Miocene deposits originating from the hydrothermal alteration of volcanic or subvolcanic rocks from the Cabo de Gata volcanic area (Almería Province) in the southern part of Spain, where the three main deposits (Cortijo de Archidona, Los Trancos, and Morrón de Mateo) were studied. The bentonites from the Tajo Basin were formed mainly by trioctahedral smectites, and there were significant mineralogical differences between the Green and Pink Clays, both in terms of the contents of impurities and in terms of smectite crystallochemistry and crystallinity. The smectites from Tamame de Sayago were dioctahedral (montmorillonite-beidellite series), and they appeared with kaolinite, quartz, and mica in all possible proportions, from almost pure bentonite to kaolin. Finally, the compositions of the bentonites from the three studied deposits in Cabo de Gata were quite similar, and zeolites and plagioclases were the main impurities. The structural formulae of the smectites from Cortijo de Archidona and Los Trancos showed a continuous compositional variation in beidellite-montmorillonite, while in Morrón de Mateo, the smectites were mainly montmorillonite, although there was continuous compositional variation from $\mathrm{Al}$ montmorillonites to $\mathrm{Fe}-\mathrm{Mg}$-rich saponites. The variation in the smectite composition is due to the intrusion of a volcanic dome, which brings new fluids that alter the initial composition of the smectites.
\end{abstract}

Keywords: bentonite; smectite; Mg clays; stevensite; saponite; montmorillonite; beidellite; kerolite

\section{Introduction}

Bentonites are very important industrial rocks, with Spain being a significant producer worldwide, since its market is very broad. They are essential in many industrial sectors, mainly as ab-adsorbents, although they are also used in several other applications, such as binders, civil engineering, drilling muds, water treatment, sand casting, and iron palletization: they are also important in animal nutrition, 
in catalysis processes, as support loads or extenders, etc. [1,2]. In recent times, the characteristics of these clays have made their uses multiply in fields as novel as nanocomposites [3], bionanocomposites [4,5], pharmaceutical preparations, and medicine, among others. The great economic importance of bentonites is due to their physical and chemical properties, mainly their surface properties and their ab-adsorption of different organic and inorganic compounds. Many studies have been carried out in the last two decades focused on organo- and inorgano-organo-modified smectites for their applications in environmental remediation technologies, mainly the remediation of contaminated/polluted aquatic environments [6,7].

The properties and industrial applications of bentonites are a consequence of their mineralogy. Bentonites are rocks composed mainly of smectites, which have laminar structure because they are phyllosilicates. Smectites are clay minerals, and they have a very small particle size (micrometric in width and nanometric in height); consequently, they have a large specific surface area. Their low layer charge and high cation exchange capacity (CEC) give them the ability to react with inorganic and organic polar reagents, principally water (hydration and dehydration), and they have swelling and rheological properties and high plasticity [8].

The genesis of Mg-rich trioctahedral smectites takes place in alkaline environments with high concentrations of $\mathrm{Mg}^{2+}$ and high salinity [9-16]. The mechanisms that enable these conditions are variable, either from direct precipitation or the transformation of pre-existing minerals, although it is difficult to differentiate between these mechanisms [17]. The processes that involve the direct precipitation of these minerals can take place due to hydrothermal solutions [18-22] and evaporitic solutions [11,23-31]. The genetic processes that involve the transformation of pre-existing mineral phases are caused by dissolution-precipitation processes [32].

In the case of dioctahedral smectites, the conditions that favor the formation of these minerals slightly vary from those of trioctahedral smectites: the environments are enriched in $\mathrm{Fe}^{3+}$ and $\mathrm{Al}^{3+}$, although the $\mathrm{pH}$ and salinity are lower [33-44]. The mechanisms that lead to the conditions under which dioctahedral smectites form are also direct precipitation and transformation processes [45-47]. The transformation processes are varied, e.g., diagenetic transformations, meteoric transformations, and dissolution-precipitation processes [14,32,42,47-51].

In Spain, there is active exploitation of bentonites in three areas: (i) the Tajo basin (Madrid-Toledo provinces), which is located in the center of the Iberian Peninsula; (ii) Tamame de Sayago (Zamora province), which is $250 \mathrm{~km}$ to the northwest of Madrid and is associated with a deposit of kaolin; and (iii) the Cabo de Gata volcanic area (Almeria province) in the southern part of Spain. The values of production in 2016 were $142 \mathrm{kt}$ in the Tajo basin, $10 \mathrm{kt}$ in Tamame de Sayago, and $3 \mathrm{kt}$ in the Cabo de Gata volcanic area, although production in Tamame de Sayago has increased notably in the last few years. A marked decline in production has taken place in the Almeria region because values reached $51 \mathrm{kt}$ in 2008. Other deposits have been important in the Calatayud Basin (Zaragoza), although since 2011 they have been inactive [52].

The studied deposits have different geological origins. The bentonites from the Tajo basin are Miocene sedimentary deposits, while the Cabo de Gata ones, also Miocene in age, originate from hydrothermal alterations of volcanic or subvolcanic rocks. The bentonites from Tamame de Sayago originate from the hydrothermal alteration of granitic Paleozoic rocks.

The aim of this work was to conduct a deep review and synthesis of the geological, mineralogical, and crystal chemical data available in the literature. At the same time, new data are provided from a set of representative samples from the three active Spanish bentonitic exploitation areas. A comparison of their mineralogical and crystal chemical features is made.

\section{Materials and Methods}

The locations, labels, and other data of the representative samples of the different deposits studied are in Table 1. The bentonites in the Tajo basin come from two different units located in the Madrid sub-basin, which are named by their colors: Green Clays and Pink Clays. The 10 samples from the Tajo 
Basin corresponded to the two main mined areas, Esquivias and the del Águila-Magán hills, and in both areas Green and Pink Clays are mined. The samples studied in this work were representative of both areas and of both Green and Pink Clays. In the same way, to study the Cabo de Gata bentonites, seven samples corresponding to the three biggest deposits were selected: three samples from Cortijo de Archidona and from Los Trancos, and one sample from Morrón de Mateo. Finally, four samples from the Tamame de Sayago Deposit (from the Navalacruz, Carboneras, and Roderica quarries) were studied.

Table 1. Main data of the studied samples, including location, labeling, approximate mineralogical composition (from X-ray powder diffraction (XRD) data), and geological origin. "Impurities" refers to the minerals that appear with the smectite: the order is related to the abundance, starting with the most abundant. Minerals between brackets are $\leq 5 \%$ in weight, and minerals with "** are at trace levels. Alu: alunite, Cpt: clinoptilolite, Fsp: feldspar, Ilt: illite, Kln: kaolinite, Ms: muscovite, Pl: plagioclase, Qz: quartz, and Stb: stilbite.

\begin{tabular}{|c|c|c|c|c|c|}
\hline Location & & rry & Label & Impurities & Geological Origin \\
\hline \multirow{10}{*}{ Tajo Basin } & \multirow{7}{*}{ Esquivias } & \multirow{3}{*}{ Green clays } & ESB 2 & Ilt, (Kln, Qz) Fsp * & \multirow{10}{*}{ Sedimentary } \\
\hline & & & ESB 3 & Ilt, (Kln, Qz) Fsp * & \\
\hline & & & ESB 6 & Ilt, Qz (Kln, Fsp) & \\
\hline & & \multirow{4}{*}{ Pink clays } & PB 10 & (Ilt) & \\
\hline & & & PB 11 & (Ilt, Qz) & \\
\hline & & & RESQ & $\mathrm{Qz}^{*}$ & \\
\hline & & & ESB 45 & (Qz, Ilt) & \\
\hline & \multirow{3}{*}{ Magán Hill } & \multirow{2}{*}{ Pink clays } & $\mathrm{MCM}$ & $(\mathrm{Qz}, \mathrm{Pl})$ & \\
\hline & & & ROS & $\mathrm{Qz}^{*}, \mathrm{Pl}^{*}$ & \\
\hline & & Green C. & VER & Ilt, Qz (Kln, Fsp) & \\
\hline \multirow{7}{*}{ Cabo de Gata } & \multirow{3}{*}{\multicolumn{2}{|c|}{ Cortijo de Archidona }} & CAR 1 & $(\mathrm{Pl})$ & \multirow{7}{*}{$\begin{array}{l}\text { Hydrothermal } \\
\text { alteration of } \\
\text { volcanic rocks }\end{array}$} \\
\hline & & & CAR 2 & (Pl) $\mathrm{Qz}^{*}$ & \\
\hline & & & CAR 3 & $\mathrm{Pl}$ & \\
\hline & \multirow{3}{*}{\multicolumn{2}{|c|}{ Los Trancos }} & LT BB & $(\mathrm{Pl})$ & \\
\hline & & & LTBV & (Pl) $\mathrm{Qz}^{*}$ & \\
\hline & & & LTBN & $(\mathrm{Pl})$ & \\
\hline & Morrón & e Mateo & MM & Mor, Cpt, (Pl) & \\
\hline \multirow{4}{*}{$\begin{array}{l}\text { Tamame de } \\
\text { Sayago }\end{array}$} & \multicolumn{2}{|c|}{ Roderica } & RodF17 & $(\mathrm{K} \ln )$ & \multirow{4}{*}{$\begin{array}{l}\text { Hydrothermal } \\
\text { alteration of } \\
\text { kaolinitized granite }\end{array}$} \\
\hline & \multirow{2}{*}{\multicolumn{2}{|c|}{ Navalacruz }} & NAV 5 & Kln, Qz, (Ms, Fsp) & \\
\hline & & & NAV 6 & $\mathrm{Qz},(\mathrm{Ms})$ & \\
\hline & \multicolumn{2}{|c|}{ Carboneras } & CarbF11 & Qz, (Ms, Fsp) & \\
\hline
\end{tabular}

Mineralogical characterization was conducted by X-ray powder diffraction (XRD). Whole-rock samples powdered in an agate manual mortar and $<2 \mu \mathrm{m}$ fractions obtained by decantation (oriented as aggregates under ambient conditions, after solvation with ethylene glycol and heating to $550{ }^{\circ} \mathrm{C}$ ) were studied. A Siemens D-500 XRD diffractometer with $\mathrm{CuK}_{\alpha}$ radiation and a graphite monochromator was employed, from $2^{\circ}$ to $65^{\circ}$ in steps of $0.05^{\circ}$ and with a 1-s/step counting time.

The geochemical analyses were performed at Activation Laboratories Ltd. (ACTLABS). Major elements and trace elements were analyzed by the package 4Lithores, which is a combination of lithium metaborate/tetraborate fusion-ICP and ICP/MS techniques (Inductively coupled plasma mass spectrometry).

The point chemical compositions were obtained using analytical electron microscopy (AEM) with transmission electron microscopy (TEM) in samples of great purity. Two different microscopes, a JEOL $3000 \mathrm{FX}$ field-emission microscope at $300 \mathrm{kV}$ and a JEM 1400 at an acceleration voltage of $120 \mathrm{kV}$, 
were used. Both microscopes incorporate an OXFORD ISIS EDX spectrometer equipped with its own software for quantitative analysis. The TEM samples were prepared by depositing a drop of diluted clay suspension on a microscopic grid with cellulose acetate butyrate and coated with graphite.

The software packages IBM SPSS version 23.0 and PAST v 217C [53] were used for the statistical analyses.

\section{Geological Features}

\subsection{The Tajo Basin}

The most important deposits of bentonite in Spain are in the Central Tajo Basin. This basin is particularly interesting because of its $\mathrm{Mg}$ clay resources, mainly sepiolite, but also $\mathrm{Mg}$ smectite. It is a Tertiary intracratonic basin of triangular shape, is about $20,000 \mathrm{~km}^{2}$, and is located in Central Spain. It was formed during the Cenozoic Alpine orogeny [54] as a consequence of the African-Eurasia plates collision. It is limited by three mountain ranges: the Central System in the north, the Toledo Mountains in the south (both formed by granites and metamorphic rocks), and the Iberian Range (which is mainly composed of carbonates and evaporitic Mesozoic rocks) to the east. The bentonites are sedimentary deposits originating from the Miocene as a consequence of the denudation and weathering of the surrounding mountains. The basin is divided into two sub-basins (the Madrid and Loranca Basins) separated by the Altomira Range (Figure 1). Both sub-basins have been filling up with sediments from the Paleocene to the Quaternary. During most of the Neogene period, the Madrid Basin was occupied by lacustrine and palustrine sedimentary deposits fringed by alluvial fans and fluvial distributary facies, forming a concentric drainage system [55]. As a consequence of the different movements of the basement during its formation, the sediments are distributed concentrically with very variable thicknesses, most of which correspond to Miocene materials. The maximum thickness, close to the Central System, is about $3500 \mathrm{~m}$.

In the Miocene sediments of the Madrid Basin, three lithostratigraphic units separated by erosive discordances have been described. From the bottom to the top, they are the Lower Unit, Intermediate Unit, and Upper Unit [56-63]

The Lower Unit, which is Ramblian to Early Aragonian in age, has a thickness that varies from 600 to $1000 \mathrm{~m}$. It overlies the Paleogene materials along an erosive discordance on the margins of the basin, but lies conformably over them in the central parts. The sediments display concentric patterns of facies distribution, as they correspond to hydrologically closed lacustrine systems (without marine connection). Close to the margins, the sediments are arkoses and litharenites deposited in an alluvial fan environment and transitional facies. The finest detrital and lacustrine sediments are deposited in mud flat environments. These transitional facies mainly correspond to red clays with interbedded anhydrite nodules. In the central part of the basin, the lacustrine sediments correspond to evaporites in which a complex mineral association, including sulphates (anhydrite, thenardite, glauberite, and polyhalite), carbonates (dolomite and magnesite), and chlorides (halite) have been recognized. The upper part of the lacustrine sediments contains exploited deposits of Na sulphates.

The Intermediate Unit overlies the Lower Unit along an erosive discordance. It was formed by Aragonian to Vallesian sediments, and their thicknesses range from 50 to $200 \mathrm{~m}$. This unit shows a clear trend toward the diminution of alluvial deposits with respect to the Lower Unit, leading to a greater development of lacustrine facies. The alluvial deposits diminish to a discontinuous band from a few hundred meters (30 km wide) along the margins of the basin. In the northern and southern margins of the basin, arkosic sands dominate, gradually transitioning to carbonate paleosols and clays in the distal facies of the alluvial fans and in the lacustrine systems. The lacustrine episodes are progressively younger from the northeast to the southwest. According to Portero and Aznar [60], the location of these lakes was controlled by the regional system of conjugated fractures (N45E and N120E). The economically important bentonites and the fibrous clays (sepiolite and palygorskite), both frequently associated with chert layers, appear in the fluvial-lacustrine transition (alluvial fans) 
facies [25,64-73]. The bentonitic units are located in the mud flat of the distal facies that is deposited along the margins of the evaporitic core of the basin, while the fibrous clays, developed as lenses, are included in the arkosic sands of the alluvial fans (Figure 2). These Mg-rich clay deposits (sepiolite and bentonites) constitute one of the world's largest sepiolite deposits (with estimated reserves greater than 100 million tons) and also very important bentonite deposits. The lacustrine sediments contain gypsum (in the southern and eastern parts of the basin) and dolomitic rocks developed in a shallow water environment.

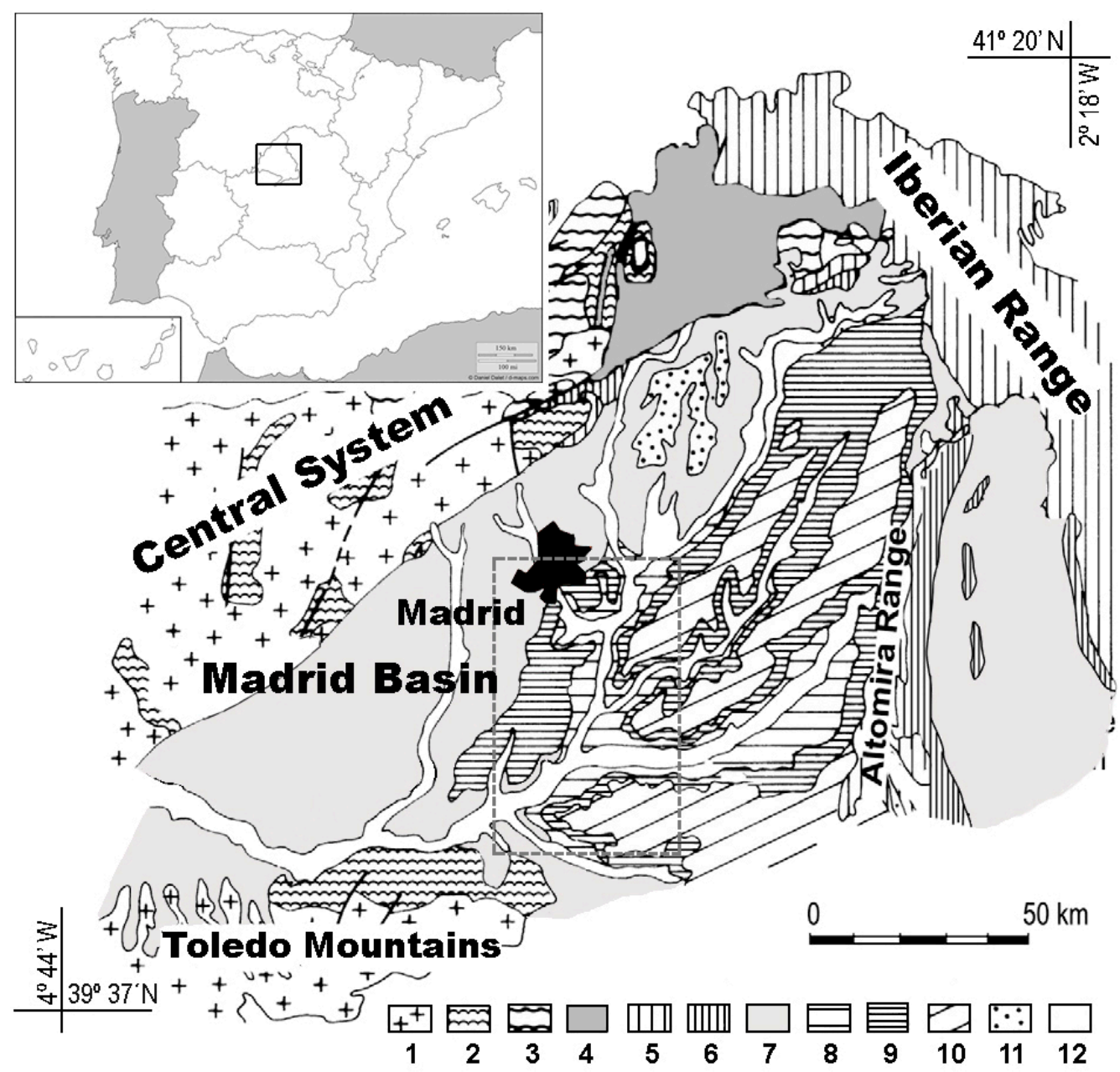

Figure 1. Geological scheme of the Tajo Basin. Variscan basement: 1, granite and granitoids; 2, high-grade metamorphic rocks; 3 , medium-grade metamorphic rocks; 4, low-grade metamorphic rocks. Mesozoic cover: 5, Cretaceous and Jurassic carbonate rocks. Cenozoic: 6, Paleogene detrital and gypsum rocks; 7, Neogene arkosic materials; 8, Miocene lower unit; 9, Miocene intermediate unit; 10, Miocene upper unit; 11, Pliocene; 12, recent sediments. Modified from Reference [63].

The Upper Unit is Vallesian to Turolian in age, and it has a maximum thickness of $50 \mathrm{~m}$. It does not show concentric facies distribution patterns, as the lower units do. It is composed of fluvial sediments (arkoses and litharenites). At the top, carbonatic rocks dominate.

This basin is particularly interesting: despite it being among the world's richest basins in terms of $\mathrm{Mg}$ clays, with big deposits of sepiolite and $\mathrm{Mg}$ smectite (which need high magnesium and silica contents to form), there is no suitable explanation for the huge amount of $\mathrm{Mg}$ needed for their formation, considering the Al-rich silicates that form most of the surrounding source areas [74]. 


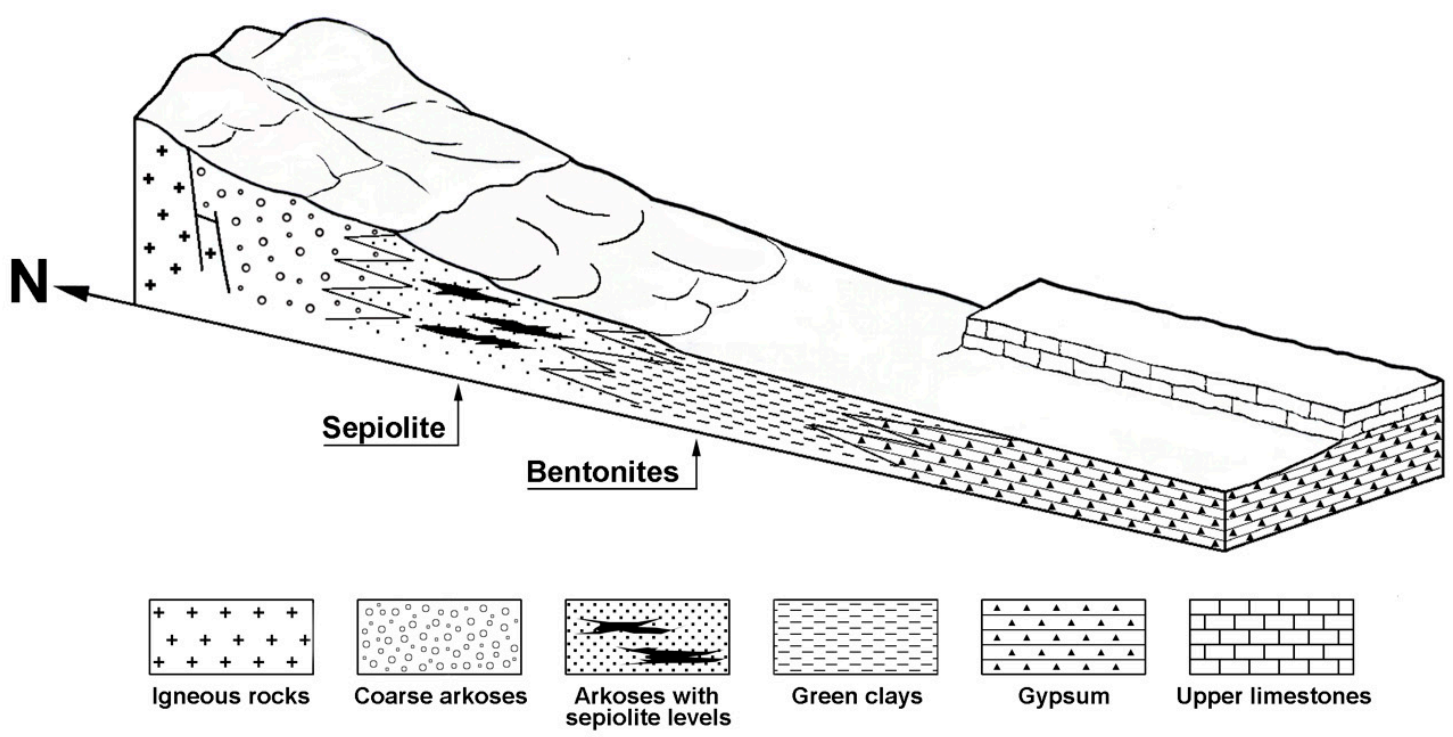

Figure 2. Facies distribution in the Madrid Basin from the Central System to the evaporitic deposits. Modified from Reference [74].

The Tajo Basin bentonite deposits are in the Green Clays of the Miocene Intermediate Unit. The unit is located to the east of Madrid in an elongated band NE-SW in direction, as shown in Figures 1 and 3 These sediments were deposited in a low-energy sedimentary environment. Sedimentologically, they correspond to mud flat facies deposited along the margins of the evaporitic core of the basin. Toward the north, the Green Clays are partially covered by Madrid and its suburbs, and they have been eroded almost completely in different areas located south of Madrid. Thus, the economically most important exploitations of bentonites are located to the south of Madrid (Madrid-Toledo area) next to the villages of Pinto, Esquivias, Seseña, Borox, and Yuncos; and also in the table hills of Cerro del Águila and Cerro de Magán next to the villages of Magán and Villaluega, respectively (Figure 3).

In general, the bentonitic units consist of a vertical succession constituted by an alternation of massive green bentonite clays, which are composed of trioctahedral smectite (mainly saponite) [64,68]. At the top of this unit, dolomitic marls or dolostones, locally silicified, may appear. Some beds of micaceous sands showing crossed or parallel lamination also occur toward the lower-middle part, and biotite and chlorite are the only phyllosilicates in these sands. A very significant feature of the Green Clays is the presence of some pinkish clay levels (Pink Clays) interbedded as irregular lenses. The Green Clays sometimes contain sepiolite nodules and isolated carbonatic nodules. Toward the top, the levels are darker and laminated. They retain bioturbation features with irregular concretions and slickensides stained by iron oxides. The Pink Clay lenses are more abundant and thicker between the localities of Pinto, Esquivias, and Seseña than in the southern part of the basin (del Águila and Magán Hills). Next to the Esquivias-Seseña area, there are two continuous levels of Green Clays approximately 1-1.5 $\mathrm{m}$ thick (Figure 4a,b), while in the del Águila and Magán Hills they are less than $0.5 \mathrm{~m}$ thick. A very significant feature of these materials is the abundance of opal concretions or irregular levels that frequently appear that are associated with both the bentonite (Green and Pink Clays) and sepiolite levels. In Figure $4 \mathrm{c}-\mathrm{e}$, there are different views of the mined levels of green bentonitic clays located at the bottom of the del Águila and Magán Hills. 


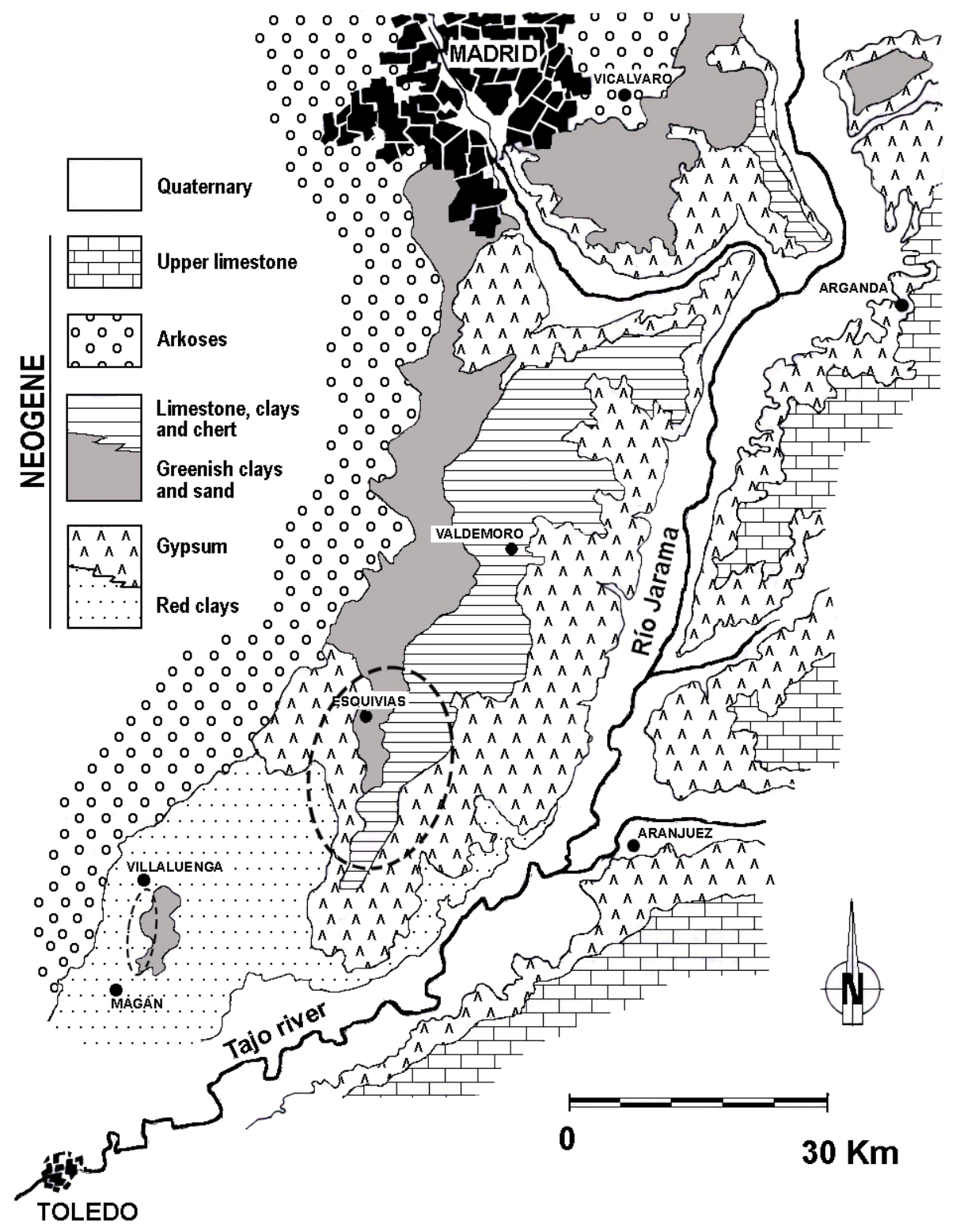

Figure 3. Geological map of the Madrid Basin. The figure corresponds to the square in Figure 1. Studied areas: dotted ellipses. Modified from Reference [72].

Both the Green Clays and the Pink Clays are mined as bentonites with industrial interest, but there are significant mineralogical differences between the Green and Pink Clays in addition to their characteristic color. In spite of Green and Pink Clays both being sedimentary deposits, they show genetic differences. The Green Clays are sedimentary deposits that correspond to mud flat facies of the alluvial fans: the detrital dioctahedral minerals became unstable in such Mg-rich environments and underwent a weathering process that resulted in the formation of trioctahedral smectites (saponites). Small amounts of detrital micas still persist in the Green Clays together with minor amounts of other detrital minerals, such as quartz and feldspars ([31,65,68,75,76], among others). The smectites that appear in the proximal areas of the alluvial fans in arkosic sediments, however, are dioctahedral [42]. On the other hand, the Pink Clays are pure smectites of stevensitic composition without detrital minerals that correspond to levels of authigenic clays newly formed in the sedimentary basin, which appear interbedded in the Green Clay unit [71]. García-Rivas et al. [77] (from the geochemistry and biomarker criteria) have concluded that the Green Clays have a more detrital character than the Pink Clays do, which present a more authigenic character. De Santiago et al. [78] (from TEM observations) 
have concluded that Pink smectites have a cellular texture that resembles descriptions of primitive clay precursors that were formed from glasses, gels, or the weathering of previous minerals. Nodules of sepiolite (newly formed) are frequently included in both Green and Pink Clays.
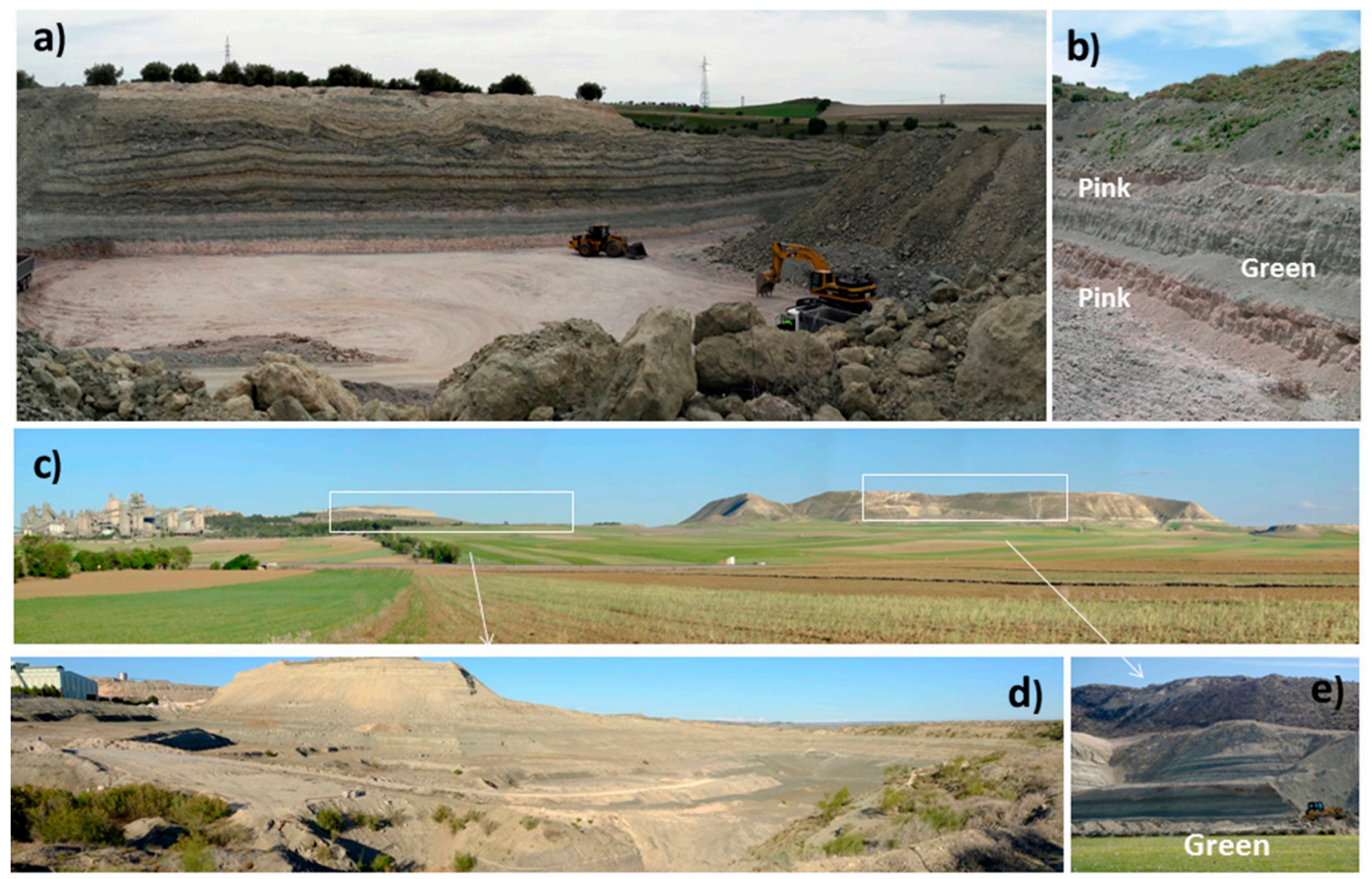

Figure 4. Representative images from Tajo Basin quarries. (a) Representative view of the Esquivias-Seseña quarries: note the alternation of green and pink clays at bottom of the quarry. (b) Detailed photograph of the green and pink colors of the bentonitic levels. (c) General view of the del Águila and Magán Hills. (d) Quarry at the bottom of del Águila Hill and (e) Quarry at the bottom of Magán Hill.

\subsection{Tamame de Sayago}

In Tamame de Sayago, the bentonites are a result of the hydrothermal alteration of a kaolinitized Variscan granite. The special clay deposit is located in the Sayago region (Figure 5) and belongs to the anatectic Variscan area of the Tormes Dome. The Tormes Dome has a surface of more than $3000 \mathrm{~km}^{2}$ and has plutonic and metamorphic rocks, which are mostly equigranular leucogranites than can be, as in the Tamame de Sayago area, peraluminous leucogranites [79,80]. The age of these granites is 310-330 Ma [81]. Prior to the end of the Cretaceous, the area was affected by an intense alteration under a wet tropical climate that produced a large kaolinitic weathering mantle [82]. With the first phase of the Alpine Orogeny, the NE-SW Late Variscan faults were reactivated, and a block tectonic, with raised and sunken blocks affecting the kaolinitized granite, took place. The weathering mantle is eroded in the raised blocks, while it is preserved in the sunken blocks due to the Late Cretaceous to Early Paleocene transition sediments that cover the kaolinitic materials [83]. Due to this tectonic activity, low-temperature silica-rich hydrothermal fluids percolated and altered the rocks, and the least variability in the mineralogy of the deposits is found in the N40E direction [84], the direction of the reactivated faults. The age of these fractures ranges between 58.8 $\pm 1.5 \mathrm{Ma}$ and $66.4 \pm 1.7 \mathrm{Ma}$ (found after K/Ar dating in alunite) [85]. This new alteration of the kaolinitized granite produced the bentonitization of big areas of the deposit. There were two phases in the circulation of low-temperature fluids [86]. The first produced the formation of millimeter-wide veins of kaolinite and minerals of the aluminum-phosphate-sulphate mineral group, such as natroalunite, plumbogummite, and arsenocrandalite [87]; the second was much more significant and resulted in the bentonitization of the deposit. The smectites were formed by percolation of the fluids in the porous kaolinitic rock, and they 
appear dispersed in the rock, filling veins and fractures. As result of these processes, kaolinite and smectite appear together in all portions of the deposit, from almost pure bentonites to pure kaolin, and the rocks in which only one clay mineral appears are scarce and are limited to the fillings of fractures [86].

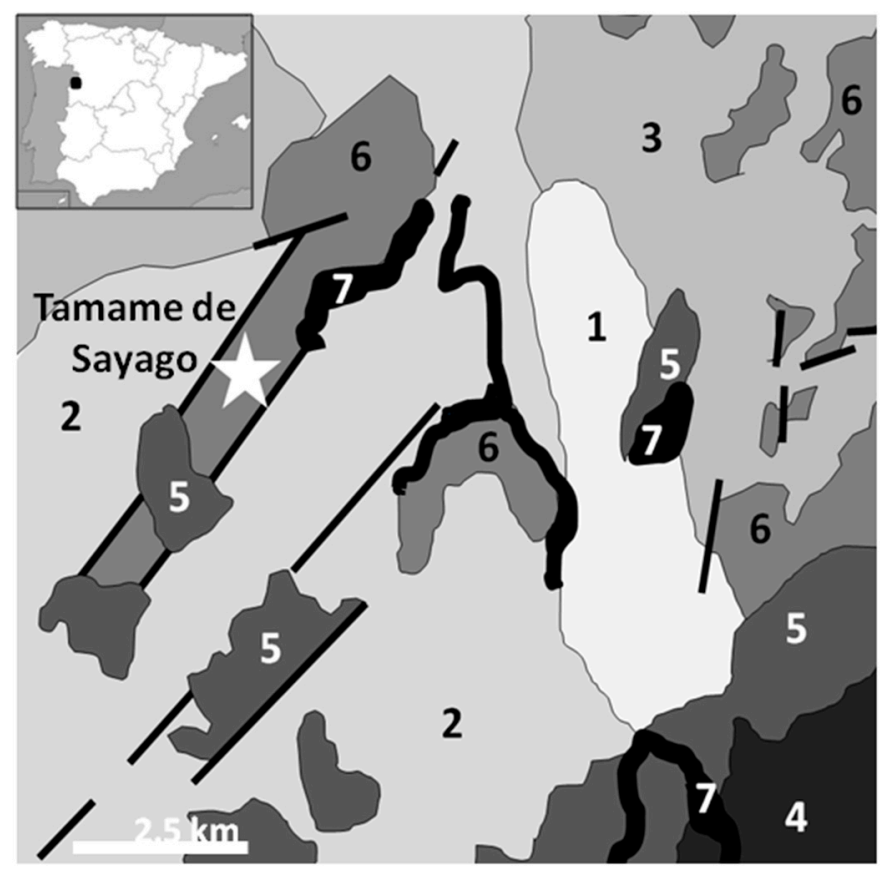

Figure 5. Geological map of the Tamame de Sayago bentonitic deposit. 1, 2, and 3: Variscan granites. 1: Coarse-grain leucogranite; 2: fine-grain leucogranite; 3: coarse-grain biotitic granitoid. 4, 5, and 6: Tertiary sedimentary materials. 4: Sands and lutites with paleosoils; 5: Paleocene siderolithic series with conglomerates, sands, and lutites; 6: Eocene-Oligocene detrital series with conglomerates, sands, and lutites; and 7: Quaternary sediments. Modified from Reference [83].

The original granitic rock has been intensely altered, and in addition, the spatial relationships between the different materials have changed due to landslides associated with fracturing, affecting soft and unconsolidated rocks close to the surface. This resulted in a chaotic distribution of the materials in the deposit, and the relation between the smectites and the faults is rarely visible. In some areas, the altered rock still retains its original texture as a regolith, but frequently it is intensely fractured and affected by landslides, so the texture is not preserved.

Kaolinite and smectite are the main minerals of the deposit, together with minor amounts of quartz and very altered micas. After intense alterations, feldspars disappeared almost completely. Occasionally, alunite and other aluminum-sulfate-phosphate solid solution minerals (APSes) occur, as has already been mentioned. They appear in veins embedded in the bentonitic areas, where eventually they can be the major minerals. Although the mineralogy is similar in the deposit, the mean composition varies considerably from the areas in which the regolith texture is preserved, named by Manchado [86] the Homogenous Alteration Zone (ZAHO), to the areas in which this texture has disappeared, named the Heterogeneous Alteration Zone (ZAHE). The predominant clay mineral in the ZAHO is kaolinite (kaolinitic areas) (mean values: 43\% kaolinite, 25\% quartz, and 18\% smectite), while in the ZAHE the main clay mineral is smectite (bentonitic areas) (mean values: $60 \%$ smectite, $18 \%$ quartz, and 13\% kaolinite). In addition, the inherited minerals from the granite are higher in the $\mathrm{ZAHO}$, while in the ZAHE the APS minerals are more abundant.

Kaolinite is mainly formed by neoformation due to the feldspar hydrolysis of the granitic rock (kaolinite in ZAHO zones), and in a second stage related to the first hydrothermal fluids, by direct precipitation from these fluids. The smectites are generated by the fluids circulating through the 
faults and percolating through the kaolinitized granite. Two processes lead to their formation: (i) the transformation of pre-existing minerals (kaolinite and micas) and (ii) neoformation or direct precipitation from hydrothermal solutions, sometimes by growth on particles of pre-existing clay minerals (epigenetic smectites) [85].

The deposit began to be benefitted from in the 1980s. At the beginning, it was exploited only as a kaolin deposit, but later it started to be exploited also as a bentonite deposit in the areas closer to the faults that are richer in smectite. Nowadays, both industrial mineral resources, kaolin and bentonite, are mined. The clays are industrially classified at the processing plant on the basis of their kaolinite/smectite content. They are obtained as different compositions that the extractor company denominates as kaolin, bentonite, or clays. The so-called kaolin is a very pure kaolinitic clay, the bentonite is a very pure smectite, and the clays correspond to mixtures of kaolinite and smectite. The micas obtained as a byproduct of kaolin are also used. There are currently four quarries in exploitation: Navalacruz, Roderica, Roderica N, and Carboneras (Figure 6).
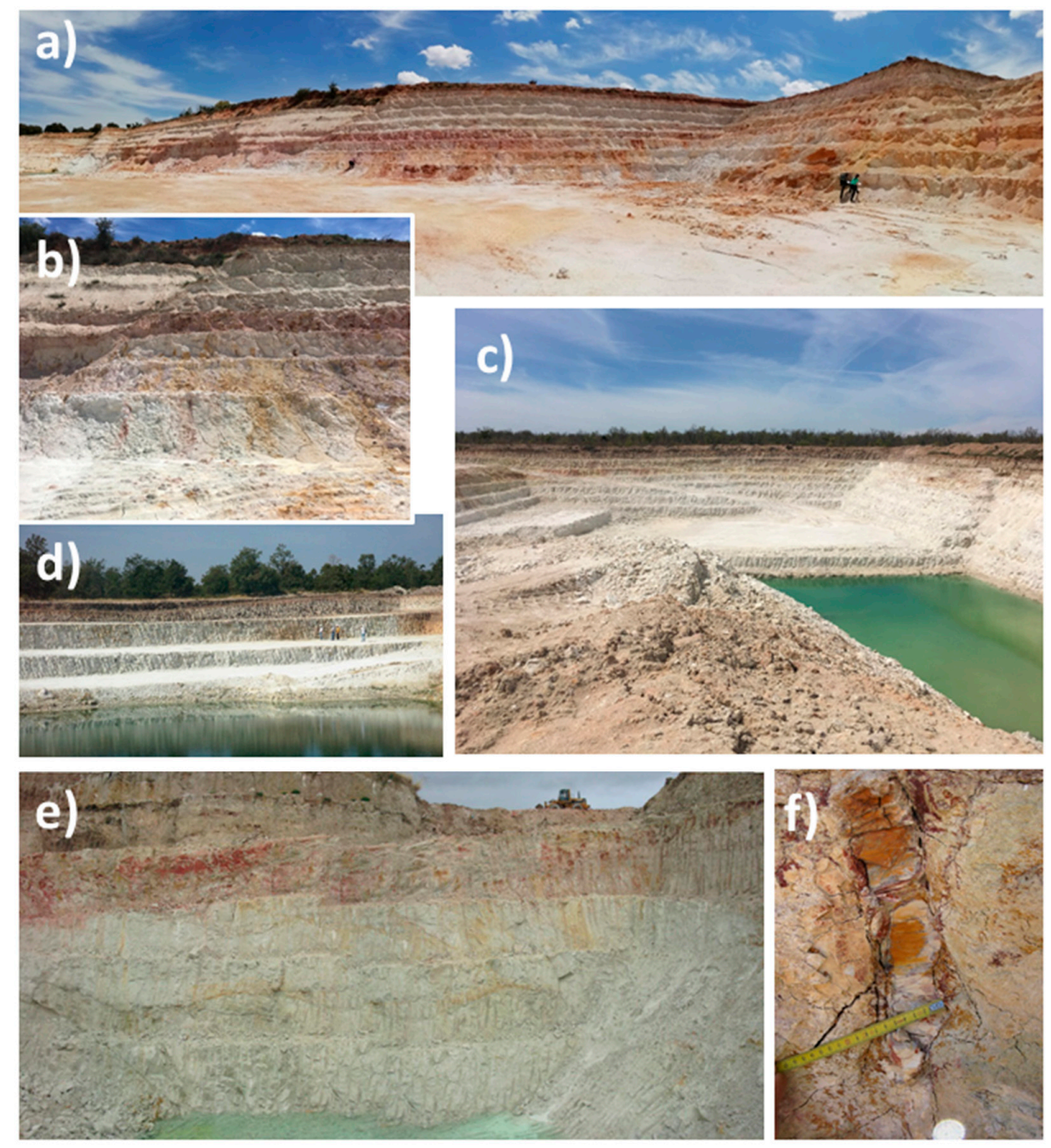

Figure 6. Representative images from the Tamame de Sayago quarries: $(\mathbf{a}, \mathbf{b})$ the Roderica quarry and (c,d) the Carboneras quarry. (e) East front of the Navalacruz quarry; (f) detailed image of a pure smectite vein in Navalacruz.

\subsection{Cabo de Gata Volcanic Region}

The volcanism in the Cabo de Gata region (southeast of the Iberian Peninsula, Figure 7 is linked to the tectonic evolution that took place in the Mediterranean area in the Middle and Late Miocene. 
Volcanic rocks appear in a narrow band that follows a general NE-SW direction from the south of Murcia Province to Cabo de Gata in Almería Province. Their presence is related to tectono-magmatic events resulting from the collision of the European-Iberian and African plates in Late Mesozoic and Middle Cenozoic times, which were replaced by extensional and strike-slip tectonics during the Miocene [88].

During the Late Oligocene-Early Miocene, the Alpine complex was folded intensively (Betic Cordillera) and later underwent an extensional collapse through major detachment systems in the Middle-Late Miocene [88,89], which is the reason for the current configuration of the complexes in the southeast of Spain. There were generalized phenomena of cortical thinning throughout the alpine domain of the Betics, Alborán, and the Rift Orogen (Morocco) [88]. The latter episode was accompanied by important calc-alkaline volcanism (andesites, dacites, and rhyolites) (Cartagena-Almería volcanic belt) and sedimentation within subsident evaporitic sedimentary basins. This episode resulted in the Alboran Basin and the Gibraltar Arc. The development of this orocline resulted in the almost complete closure of the Mediterranean Sea and may have been the triggering event leading to the so-called salinity crisis (Messinian times), which resulted in extensive evaporite deposits in the Mediterranean basin [90].
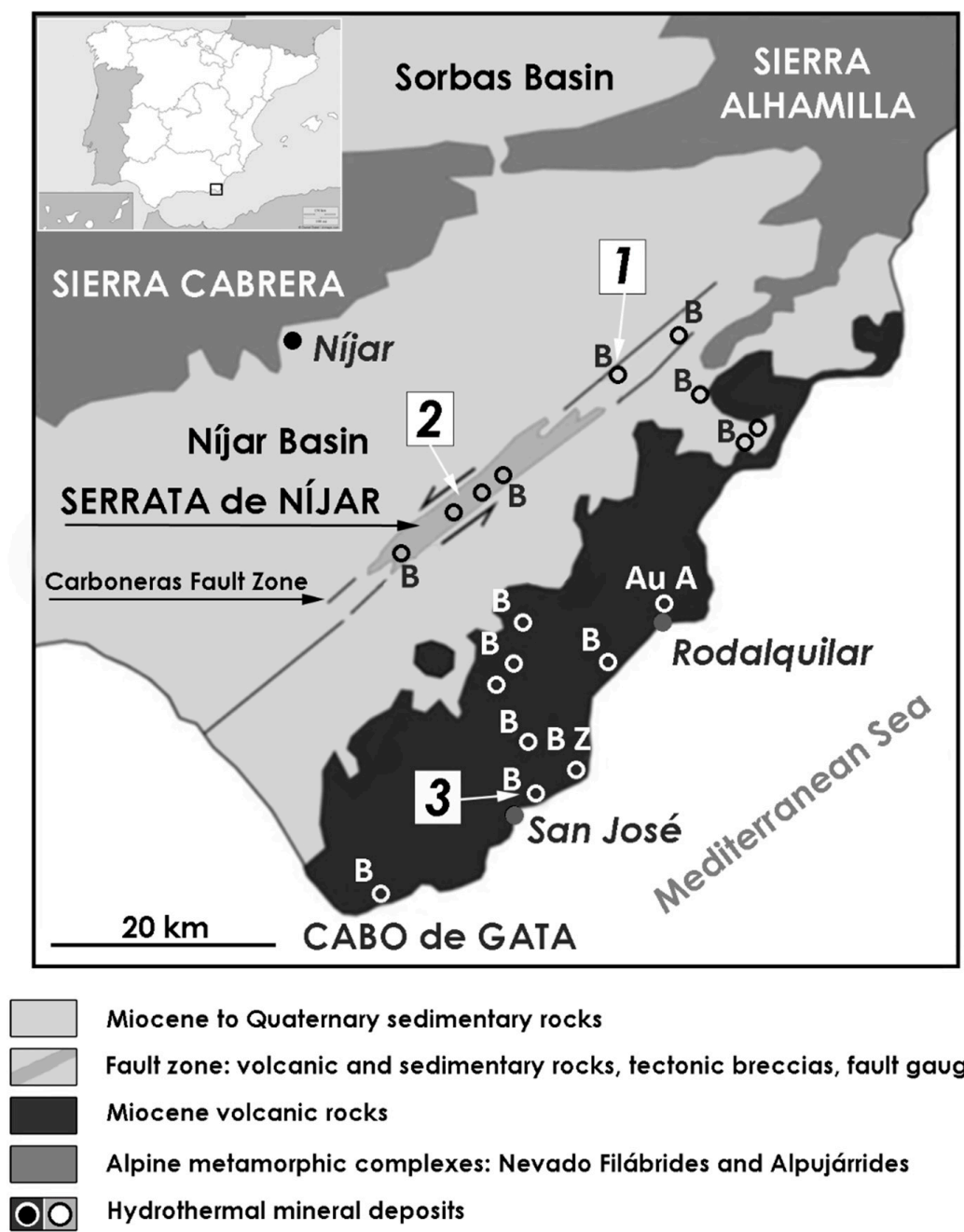

Miocene to Quaternary sedimentary rocks

Fault zone: volcanic and sedimentary rocks, tectonic breccias, fault gauge

Miocene volcanic rocks

Alpine metamorphic complexes: Nevado Filábrides and Alpujárrides

Hydrothermal mineral deposits

Figure 7. Simplified scheme depicting the major geological units of the Cabo de Gata region and the location of the studied quarries. 1: Los Trancos. 2: Cortijo de Archidona. 3: Morrón de Mateo. A: alunite; Au: gold; B: bentonite, Z: zeolite. Modified from [91]. 
Magmatism took place in a shallow marine environment, so the sequences are characterized by the intercalation of volcanic materials with continental and marine sedimentary deposits. Domes, volcanic flows, and pyroclastic rocks can be found within a wide compositional range. The most representative rocks are andesites, dacites, and rhyolites, so the eruptions were explosive, with a predominance of materials produced by the collapse of eruptive columns and domes, such as pyroclastic flows, blocks and ash, base surges, and ignimbrites. The lava materials are predominantly basaltic andesites or andesites [90].

Subsequent large $(+40 \mathrm{~km})$ ENE-WSW sinistral wrench faulting during the Miocene (Carboneras Fault Zone) [92,93] gave rise to the formation of remarkable morphological features in the Nijar-San Jose sector (the so-called Serrata de Nijar), a compressive duplex characterized by large-scale pervasive deformation of the Miocene sedimentary and volcanic units.

The continuous circulation of meteoric or marine hydrothermal waters through the volcanic materials in Cabo de Gata gave way to a generalized bentonitization of the area. Throughout their geological history, the volcanic materials of Cabo de Gata have been affected by hydrothermal alteration processes produced by meteoric, marine, or hydrothermal waters, giving way to important mineralogical changes and formations in the zone of mineral deposits. These processes were developed in sectors partially covered by a warm and shallow sea, in which corals grew. The circulation of fluids along fractures and contact surfaces between materials produced the mineral dissolution, mobilization, and accumulation of chemical elements and the genesis of ore deposits (epithermal gold ore deposits associated with the Rodalquilar Caldera and zeolites and bentonite deposits). In the Cabo de Gata area, more than 30 outcrops of bentonite have been described, which were formed by hydrothermal alterations of acid volcanic rocks (dacite and rhyolite). Often, the deposits are small outcrops of altered volcanic material. The processes involved the mobilization of silica, Fe, alkali, and also $\mathrm{Mg}$ in some zones. The alterations depended on the rock type as well as on the chemical composition, origin, and temperature of the solutions.

The bentonitization, which was more or less intense depending on the lithology and the features of the affected materials, resulted in numerous exploitable deposits (Figure 7). They are mainly linked with pyroclastic units that include ignimbrites, alternations of fall and base surges, or agglomerates and tuffs. More than 30 small deposits throughout the region have been exploited (from Nijar to San José, through the Sierra de Nijar), many of them since the 1950s. Nevertheless, nowadays production has fallen significantly, from $51 \mathrm{kt}$ in 2008 to $3 \mathrm{kt}$ in 2017.

The geothermal system that operated in the Cabo de Gata region must have been very simple [94,95]. Probably, meteoric waters infiltrated the great fracture system of the region. The aquifers probably followed a N-S trend toward the sea. The recharge sources of the aquifers have probably been the Alhamilla and Cabrera Sierras, located to the north of the deposits. Once heated, the meteoric waters penetrated the different porous cineritic levels, altering them into bentonites. On the basis of stable isotopes, the estimated temperature of the hydrothermal fluids that gave rise to the bentonites should have been around $70{ }^{\circ} \mathrm{C}$ in the case of bentonites of the Sierra de Gata and about $40{ }^{\circ} \mathrm{C}$ in The Serrata de Nijar [96]. Going to the south, the bentonites are more siliceous and ferric and contain less sodium $[97,98]$.

The bentonite deposits of Cabo de Gata are classified according to their geographical location [97-100] into three main groups. The first is the Serrata de Nijar bentonitized areas, which have numerous outcrops, including Cerro Colorado, Collado del Aire, Pecho de los Cristos, Palma del Muerto, and the most important deposit, Cortijo de Archidona. The second is the northern zone of Sierra del Cabo de Gata. In addition to Los Trancos, the most important deposit in this area, numerous minor deposits have been described and exploited: Mata Lobera, Rambla Vieja, Rambla del Agua, Rincón de las Calderas, Jayón, Pozo Usero, La Valentina, Majada de las Vacas, Plomo, Cala Montoya, Bornos, and Hortichelas. The third is the southern zone of Sierra del Cabo de Gata. In this área, different outcrops can be found: Cortijo de la Loma, Cerro Amatista, Los Escuyos, Cortijo del Gitano, La Isleta del Moro, La Capitana, Las Hermanicas, and Morrón de Mateo are the most important. 
The Cortijo de Archidona deposit is located in the SE extreme of the Serrata de Nijar (Figure 7). The Serrata de Nijar is a set of hills $12 \mathrm{~km}$ long and $1.5 \mathrm{~km}$ wide that is delimited by two NE-SW fractures that belong to a horst parallel to the Cabo de Gata Range. The Serrata de Nijar can be regarded as an uplifted tectonic block formed within a transpression zone developed along the Carboneras Fault Zone. This sector is characterized by faulting at different scales, with brecciation and the development of large zones of fault gouge. The sedimentary units (limestone and gypsum beds) were folded intensively, whereas the volcanic rocks were either tectonically brecciated or transformed into massive zones of fault gouging [91]. The relation between the bentonitization of the area and the widespread hydrothermal processes along the Serrata de Nijar and the surrounding areas, which happened during ongoing deformation in the Carboneras Fault Zone, is evident, and thus the relation between mineralization and fracturation is evident in the region.

The Cortijo de Archidona (Figure 8) deposit occurs in two preferred directions, which coincide with two fracture zones with NW-SE and NE-SW directions. The most import mining works are NW-SE-oriented, following the principal fracture zone. The original materials were vesicular dark-colored rhyodacites, glasses, and weakly colored ignimbrites. Solutions with neutral or slightly acidic $\mathrm{pH}$ were responsible for the alteration of the volcanic materials [96,97]. The processes of alteration were favored by the intense brecciation present in the rocks. The bentonites have high purity, with quartz, feldspars, and amphiboles as impurities. The deposit is $85-98 \%$ smectite and $1-4 \%$ inherited minerals from volcanic rocks such as quartz, plagioclase, biotite, and pyroxenes, together with cristobalite and calcite as secondary minerals [101].

The Los Trancos deposit is located in the north of the Sierra de Gata (Figure 7), and it is the biggest deposit in the Cabo de Gata volcanic region (Figure 8). It developed through two large fractures oriented N10E and N60E that affected rich glass tuffs and agglomerated materials of dacitic $[98,99,102]$ or rhyodacitic composition [103]. The thicknesses of the bentonite layers vary between 10 and $50 \mathrm{~m}$, and they can exceed even $60 \mathrm{~m}$ in some places. The tuff alteration to bentonite happened due to the presence of intense fracturing and the intrusion of domes, which led to occasional alteration because of a thermal effect. Three bentonite types are mined, and they are named according to their color: green, white, or black (of gray color) bentonites. They are very pure bentonites that can be almost $100 \%$ dioctahedral smectite. There is a possible presence of mixed layers of smectite-kaolinite [104]. They can contain scarce proportions of quartz, plagioclase, and biotite that are inherited from the original acid volcanic rocks, and sometimes they can contain very scarce secondary cristobalite and calcite.

Morrón de Mateo (Figure 8) is located in the southern zone of the Cabo de Gata Range (Figure 7). It was also formed by the alteration of pyroclastic materials of andesitic composition with heterogeneous epiclastic mass flow. It consists, from the bottom to the top, of (i) hornblende-rich andesitic breccias, (ii) white layered tuffs (white tuff formation), (iii) marine sedimentary rocks (biocalcarenite beds), and (iv) bentonitized epiclastic rocks (mass flow formation) [105]. The volcano-sedimentary series were affected by the intrusion of a dacitic dome (Morrón de Mateo, $197 \mathrm{~m}$ high). The dome age is between 10.8 and 11.3 Ma [105], and it is composed of biotite-hornblende, quartz-rich dacites, with a characteristic red to ochre tint (Figure 8) that is related to the nearby Rodalquilar caldera complex [106]. The dome intrusion induced a temperature increase and a supply of Fe-Mg-rich solutions, which were responsible for the alteration of the previously bentonitized pyroclastic materials (white tuff formation) [105-108].

The white tuff formation is composed of a succession of white-colored soft layers of bentonite-rich tuffs and tabular layers of a brownish to greenish sandy material (poorer in bentonite), which form base surge and co-surge hydromagmatic facies. The sequence of white tuffs is subhorizontal or slightly dips to the east, but the intrusion dragged and folded the layered sequence in close proximity. It is more than $50 \mathrm{~km}$ wide, and it may reach a thickness of 60-70 m, decreasing eastward and showing some sedimentary structures that point to lateral currents as the main transport and deposition mechanisms. These features suggest that the white tuffs may have formed as a result of phreatomagmatic activity 
occurring through magma-water interactions in a shallow marine environment, probably in a depressed coastal embayment $[101,106]$.
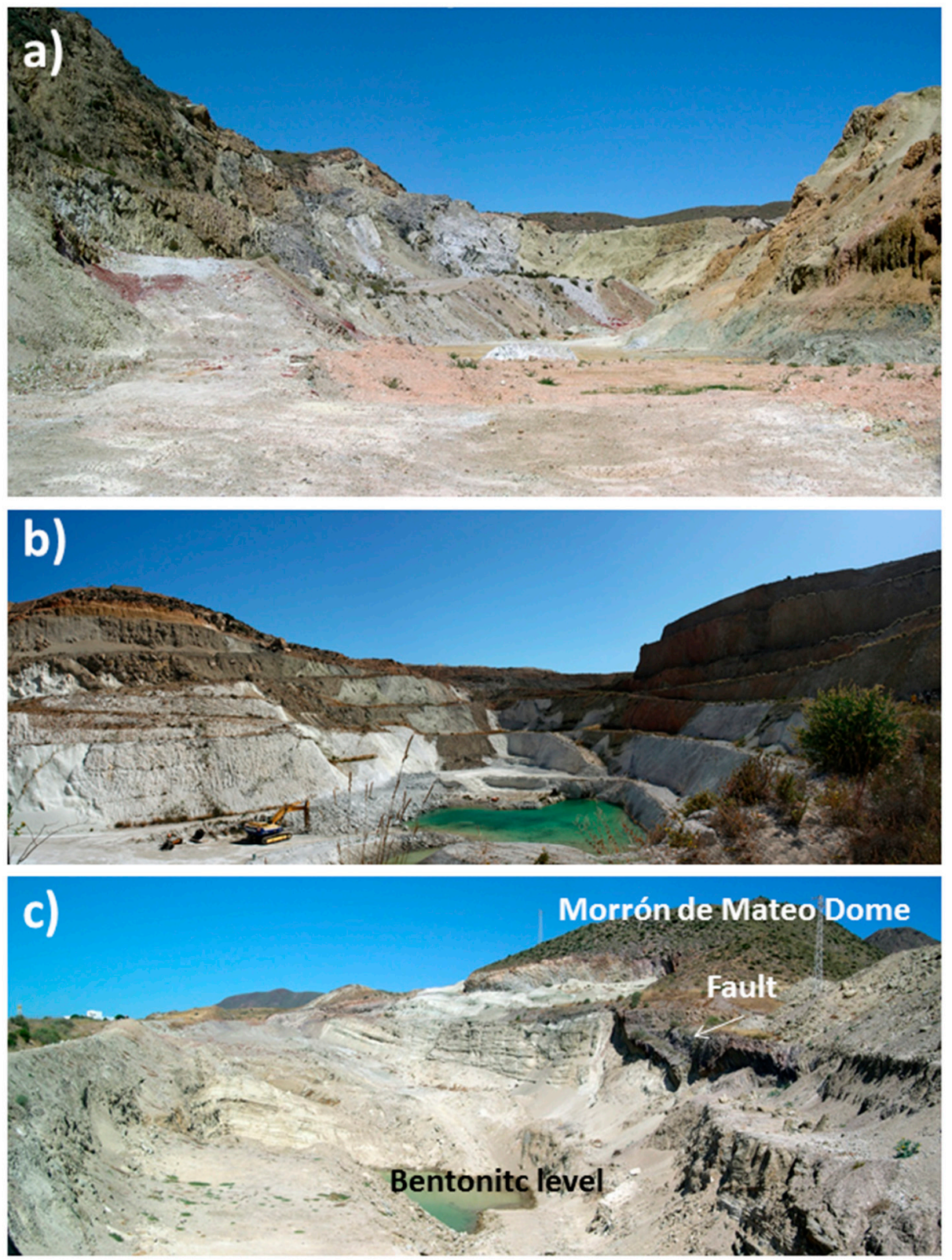

Figure 8. Representative images from the Cabo de Gata quarries. (a) The Cortijo de Archidona quarry; (b) the Los Trancos quarry; and (c) the Morrón de Mateo quarry. Note the dome intrusion in the Morrón de Mateo picture and the fault between the dome and the bentonitic levels.

There are notable differences between the smectites of the different levels that alternate in the deposit. These differences in composition have been interpreted as due to the compositional differences of the rock before alteration $[107,108]$. Zeolites such as ferrierite and clinoptilolite are present as impurities in the smectites [101]. The white tufts contain the highest content of phyllosilicates (montmorillonite), while the mass flow contains more primary minerals and the phyllosilicates beidellite and corrensite $[107,108]$. These authors also stated that the smectites of the mass flow formation have a higher content of $\mathrm{Fe}$ and $\mathrm{Mg}$ and greater chemical heterogeneity as a consequence of the nature of the parent rock, and they inferred that the formation of corrensite in the Morrón de Mateo area took place after the process of bentonitization, which affected the pyroclastic rocks. The corrensite 
formed due to an incipient process of propylitic alteration in the area that transformed part of the neoformed smectite into corrensite. This transformation was probably favored by the intrusion of the dome, which provided hydrothermal solutions rich in Fe and Mg.

The Morrón de Mateo deposit has been studied as a natural analogue of the thermal and geochemical effects on clayey barriers in deep geological repositories of high-level radioactive wastes. The results obtained showed that the distal smectites are $\mathrm{Al}$ montmorillonites that are similar to those in other bentonite deposits in the Cabo de Gata region, whereas the proximal smectites are a mixture of Al montmorillonites, Fe-rich montmorillonites and beidellites, and intermediate smectites between beidellite and Fe-rich saponite $[107,108]$.

\section{Mineralogy and Chemistry of Bentonites}

Although all of the samples studied corresponded to bentonites, there were remarkable differences between them, both in terms of the type of smectite and in terms of the impurities they contain because of the different genetic processes related to their formation. In this section, mineralogical compositions (from XRD of whole-rock and oriented aggregates) of representative samples coming from the main deposits of the three studied areas are shown. Whole-rock X-Ray diffraction patterns of a group of representative samples of each area are shown in Figure 9.

There were significant differences between the mineralogical compositions of the Green and Pink Clays. The XRD patterns of raw of ROS and VER samples are shown in Figure 9: in these two samples, as in all bentonites from the Tajo Basin, the trioctahedral character of the smectites could be deduced through the position of the 060 reflection that appears at $0.152 \mathrm{~nm}$. The samples of Green Clays (ESB 2, ESB 3, ESB 6, and VER) contained quartz and illite as impurities, together with small amounts of feldspar. Minor amounts of other phyllosilicates (sepiolite or kaolinite) could be detected occasionally (Table 1). On the other hand, the Pink Clays (samples PB10, PB11, RESQ, ESB 45, MCM, and ROS) were very pure, and only $0 \mathrm{kl}$ reflections of smectite appeared in the XRD patterns of the powdered samples. The low crystallinity of the smectites in the Pink Clays, without ordering in the [001] direction, was remarkable. In the region of the higher d-spacings, there was no 001 reflection; on the contrary, there was only a very wide band in the lower angles that finished at $\sim 1.0 \mathrm{~nm}$. Although the XRD patterns of Pink Clays exhibited a very broad band, a difference between oriented aggregates before and after glycolation could be seen, indicating the swelling of the smectite layers (Figure 1, Supplementary Materials). This may have been related to the lack of three-dimensional periodicity due to arbitrary rotation or sliding between the layers, giving rise to extensive stacking disorder $[78,109]$. These authors assume that this phenomenon was related to particle size and textural features.

Dioctahedral smectites appeared in all possible proportions in the Tamame de Sayago deposit, as has been pointed out previously. The bentonitic materials were composed mainly of dioctahedral smectite (the 060 reflection appeared at $0.149 \mathrm{~nm}$ ) with variable amounts of impurities, mainly quartz, mica, and kaolinite, as shown in Figure 9. The crystallinity of these smectites was very high, with a narrow 001 reflection, in relation to their hydrothermal origin, enabling good crystal growth. In most of the bentonitic samples, smectites were almost the only mineral (in veins and closer to the fault areas).

The XRD patterns were very similar for all of the samples studied from the Los Trancos deposit (the green (LTBV), white (LTBB), and black (LTBN) bentonites) and from the Cortijo de Archidona deposit (CAR 1, CAR 2, and CAR 3) (Figure 9). The X-ray diffraction patterns of these samples exhibited characteristic smectite hk0 reflections. The main peak, at $1.5 \mathrm{~nm}$, was narrow and showed high $I_{001} / I_{020}$ values, indicating good crystallinity. All of the studied samples from these deposits showed high purity, with very small proportions of plagioclase, and there was also quartz in sample CAR 2. Traces of crystobalite were also found in sample CAR 1. In a sample from the Los Trancos deposit, small amounts of phyrophillite were identified [110], while in a wider study of this deposit, variable amounts of calcite $(0-15 \%)$ and minor proportions $(0-5 \%)$ of zeolite, trydimite, biotite, or K-feldspar were also identified [102]. 


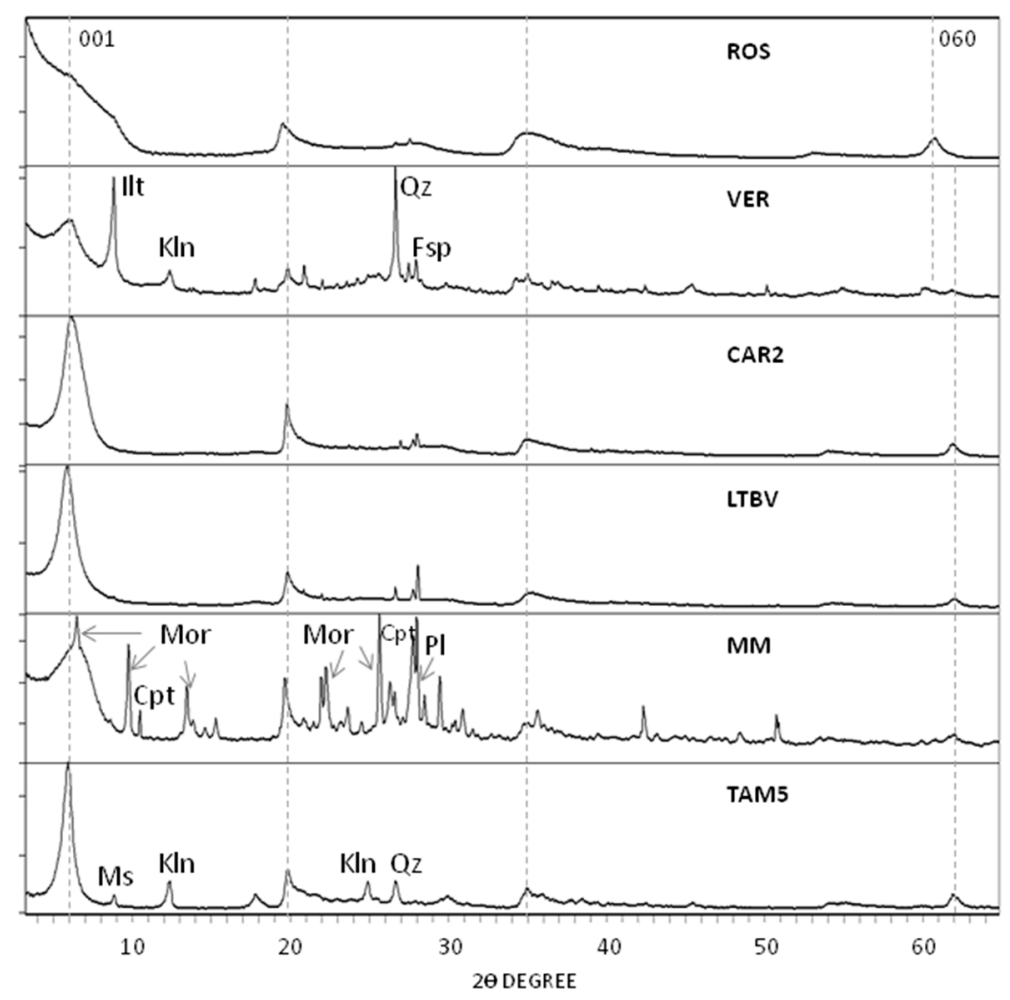

Figure 9. Representative X-ray diffraction patterns of whole-rock powder samples. Cpt: clinoptilolite, Fsp: feldspar, Illt: illite, Kln: kaolinite, Mor: mordenite, Ms: moscovite, Pl: plagioclase, Qz: quartz. Dashed line, from the left to the right: 001, 020, 131, and 060 smectite reflection.

The mineralogical composition of the bentonites from the Morrón de Mateo deposit is a bit more complex. As shown in Figure 9, zeolites (clinoptilolites and mordenite) appeared as the main impurities, together with plagioclase. A similar mineralogical composition was identified in Reference [102], in addition to variable amounts of amphibole, biotite, calcite, and K-feldspar in the poorest samples of smectite. Zeolites and small amounts of amphiboles and calcite have also been found in this deposit [108].

The results of the chemical analyses (major elements) of the representative bulk rocks from the studied deposits are in Table 2. They corresponded, in agreement with the mineralogical compositions obtained by $\mathrm{XRD}$, to very clayey samples with small influences from impurities in some of them. The higher variations were in the $\mathrm{MgO}(2.03-25.39 \%)$ and $\mathrm{Al}_{2} \mathrm{O}_{3}(1.61-19.88 \%)$ contents, according to the presence of both dioctahedral and trioctahedral smectites as major mineral components in the samples. Consequently, the correlation coefficient between these two oxides was negative and very high (-0.959) (Table S1 in Supplementary Materials). The $\mathrm{MgO}$ content varied between $10.40 \%$ and $25.39 \%$ in the samples from the Tajo Basin, which contained more trioctahedral smectites, while this oxide was minor in the samples from Tamame de Sayago and Cabo de Gata. The hierarchical clusters obtained by Ward's method, which considered the contents of the three main oxides constituting smectites, showed an almost perfect grouping of the samples from the same deposits (Figure 10). The samples from Cabo de Gata and Tamame de Sayago were in two different clusters but were grouped together and separated from the trioctahedral smectites from the Tajo Basin. The sample from Morrón de Mateo probably appeared in the cluster of samples from Tamame de Sayago due to the influence of its zeolite impurities, because zeolites contribute the same elements as muscovite.

On the other hand, the influence of some impurities could also be noted not only by the contents in some oxides but also by their correlations (Table S1, Supplementary Materials). The positive correlation coefficients of $\mathrm{Fe}_{2} \mathrm{O}_{3}$ with $\mathrm{K}_{2} \mathrm{O}$ and $\mathrm{TiO}_{2}$, both higher than 0.61 , and of $\mathrm{K}_{2} \mathrm{O}$ with $\mathrm{TiO}_{2}(0.864)$, were related to the higher contents of these oxides in the Green Clays from the Tajo Basin due to the presence 
of small amounts of biotite. The highest contents in $\mathrm{CaO}$ and $\mathrm{Na}_{2} \mathrm{O}$ were in sample $\mathrm{MM}$ due to its zeolite content.

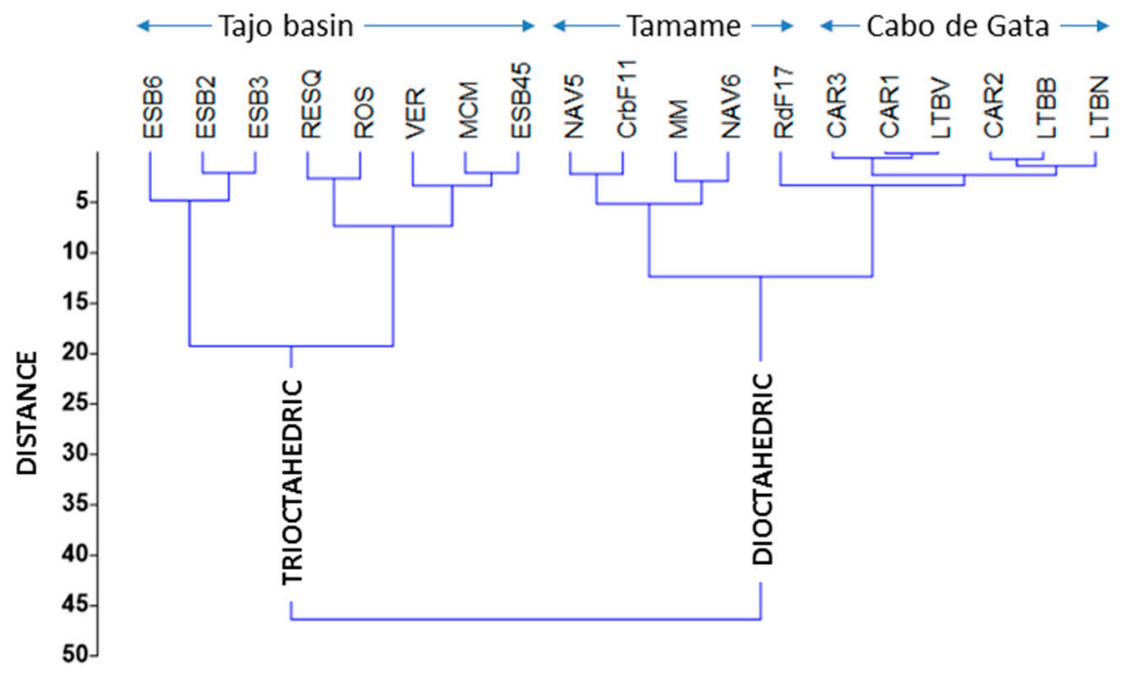

Figure 10. Hierarchical cluster obtained by Ward's method considering the contents of the three main oxides $\left(\mathrm{SiO}_{2}, \mathrm{Al}_{2} \mathrm{O}_{3}\right.$, and $\left.\mathrm{MgO}\right)$.

The trace elements analyzed in the samples (Table S2, Supplementary Materials) were characteristic of each deposit and were related to their genesis. Therefore, the results were similar for the samples from the same deposits, as can be seen in Figure 11, where the values of the sum of LREEs (light rare earth elements) and HREEs (heavy rare earth elements) are represented and the samples from the same deposits appear plotted in narrow areas, with the exception of samples from Tamame. The dispersion of the values for the samples from Tamame originated from the characteristic heterogeneity of this deposit due to the sum of two alteration processes in the original granite. There were materials in which the influence of hydrothermal processes that changed the mineralogical and chemical composition of the kaolinitized granite was higher than in others, as in sample RodF17, which corresponded to a vein and is plotted very far from the others.

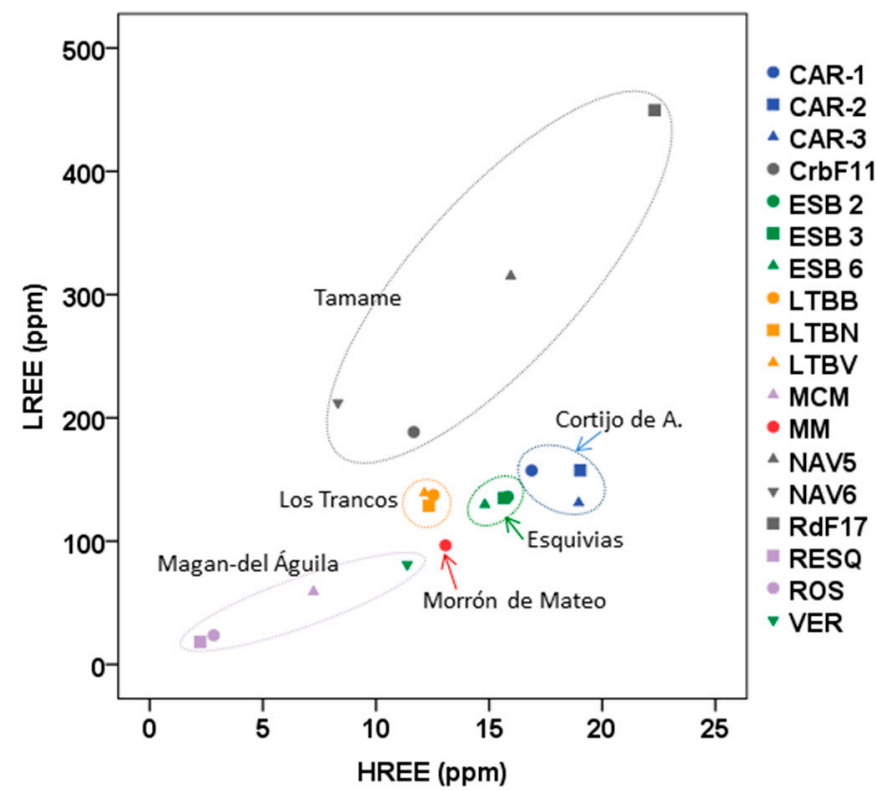

Figure 11. LREEs (light rare earth elements) versus HREEs (heavy rare earth elements). 
Table 2. Contents of major elements. Values in wt \% oxides. LOI: loss of ignition.

\begin{tabular}{ccccccccccccc}
\hline & $\mathrm{SiO}_{2}$ & $\mathbf{A l}_{\mathbf{2}} \mathbf{O}_{\mathbf{3}}$ & $\mathbf{F e}_{\mathbf{2}} \mathbf{O}_{\mathbf{3}}$ & $\mathbf{F e O}$ & $\mathbf{M n O}$ & $\mathbf{M g O}$ & $\mathbf{C a O}$ & $\mathbf{N a}_{\mathbf{2}} \mathbf{O}$ & $\mathbf{K}_{\mathbf{2}} \mathbf{O}$ & $\mathbf{T i O}_{\mathbf{2}}$ & $\mathbf{P}_{\mathbf{2}} \mathbf{O}_{\mathbf{5}}$ & $\mathbf{L O I}$ \\
\hline ESB 2 & 48.55 & 11.52 & 3.70 & 0.40 & 0.04 & 15.90 & 0.67 & 0.27 & 2.02 & 0.52 & 0.11 & 15.96 \\
ESB 3 & 50.80 & 12.76 & 3.49 & 0.90 & 0.04 & 14.58 & 0.53 & 0.40 & 2.22 & 0.60 & 0.08 & 14.09 \\
ESB 6 & 50.75 & 14.01 & 3.88 & 0.90 & 0.03 & 10.40 & 0.77 & 0.48 & 2.91 & 0.48 & 0.20 & 14.56 \\
ESB 45 & 51.62 & 5.15 & 1.51 & 0.25 & 0.02 & 23.07 & 0.68 & 0.16 & 0.90 & 0.24 & 0.08 & 16.67 \\
MCM & 52.08 & 6.21 & 1.79 & $<0.1$ & 0.03 & 20.41 & 0.56 & 0.39 & 1.54 & 0.22 & 0.04 & 15.49 \\
VER & 48.85 & 6.64 & 2.33 & 0.17 & 0.03 & 20.96 & 0.68 & 0.22 & 1.24 & 0.31 & 0.11 & 17.52 \\
ROS & 52.15 & 2.11 & 0.71 & $<0.01$ & 0.01 & 25.39 & 2.63 & 0.05 & 0.40 & 0.11 & 0.05 & 17.03 \\
RESQ & 48.56 & 1.61 & 0.71 & $<0.01$ & 0.02 & 24.52 & 2.76 & 0.03 & 0.33 & 0.08 & 0.04 & 21.66 \\
NAV 5 & 57.79 & 19.88 & 1.53 & 0.00 & 0.00 & 2.03 & 1.52 & 0.18 & 0.93 & 0.21 & 0.37 & 15.20 \\
NAV 6 & 60.58 & 16.21 & 1.77 & 0.00 & 0.00 & 3.02 & 1.96 & 0.13 & 0.79 & 0.29 & 0.16 & 14.63 \\
RodF17 & 52.37 & 19.51 & 2.10 & 0.00 & 0.00 & 3.87 & 1.88 & 0.11 & 0.49 & 0.09 & 0.18 & 20.17 \\
CarbF11 & 57.49 & 17.01 & 2.49 & 0.00 & 0.01 & 3.10 & 1.61 & 0.11 & 1.29 & 0.40 & 0.10 & 17.38 \\
CAR 1 & 51.42 & 16.92 & 2.52 & $<0.1$ & 0.09 & 4.71 & 1.31 & 0.94 & 0.55 & 0.17 & 0.02 & 19.93 \\
CAR 2 & 51.99 & 16.83 & 3.26 & $<0.1$ & 0.02 & 4.31 & 1.10 & 1.17 & 0.44 & 0.16 & 0.03 & 19.27 \\
CAR 3 & 50.73 & 17.30 & 2.46 & $<0.1$ & 0.04 & 4.72 & 1.30 & 0.98 & 0.35 & 0.15 & 0.03 & 20.36 \\
LTBB & 52.12 & 17.75 & 2.41 & $<0.1$ & 0.11 & 4.56 & 1.29 & 0.51 & 0.14 & 0.20 & 0.03 & 20.77 \\
LTBV & 51.25 & 17.01 & 2.31 & $<0.1$ & 0.08 & 4.78 & 1.32 & 0.51 & 0.43 & 0.17 & 0.06 & 20.61 \\
LTBN & 53.47 & 17.21 & 2.21 & $<0.1$ & 0.09 & 4.87 & 1.05 & 1.07 & 0.27 & 0.16 & 0.03 & 19.42 \\
MM & 57.38 & 13.84 & 2.48 & 0.20 & 0.02 & 2.28 & 4.15 & 2.32 & 0.90 & 0.36 & 0.08 & 14.87 \\
\hline
\end{tabular}

\section{Smectite Crystal Chemistry}

The structural formulae calculated from the mean values of the smectite point analyses obtained by AEM are listed in Table 3. Some other structural formulae proposed by different authors in previous works for samples of the studied bentonites appear in Table 4.

The structural formulae of the smectites from the Tajo Basin samples, both for the Green and Pink Clays and in accordance with the XRD pattern deductions, corresponded to trioctahedral smectites, mainly saponite. They had high $\mathrm{MgO}$ contents that ranged from $14.27 \%$ to $34.03 \%$ versus much minor proportions of $\mathrm{Al}_{2} \mathrm{O}_{3}$, which ranged between $1.30 \%$ and $18.99 \%$ (Table 3). The number of octahedral cations for a unit cell varied from 5.04 to 6.14. The charge layer was low (from 0.08 to 0.44 ) in all of the samples, and the tetrahedral charge was higher than the octahedral charge, so the samples had to be classified as low-charge saponite. One of the samples (RESQ) had 6.14 octahedral cations. In addition, this sample had the lowest charge (0.08), so it was classified as kerolite instead of saponite. If some of the $\mathrm{Mg}$ in this sample had been in the interlayer as an exchangeable cation, the number of octahedral cations would have been small and the layer charge would have corresponded to a smectite instead of a kerolite. Taking into account the high Mg content in all of the samples from the Tajo Basin, it would be reasonable to think about the possibility of a part of the $\mathrm{Mg}$ being present as interlayer cations instead of octahedral cations. In that case, the layer charge would have been higher, corresponding to smectite. This probably happened in most or all of the samples from the Tajo Basin and is the reason that explains the positive charge of the octahedral sheet and the low interlayer charge obtained.

As shown in Table 4, there is agreement about the saponitic character of the Green Clays. However, the Pink Clays have been classified as stevensite [25,78,111], kerolite [28], kerolite-stevensite [76,109], and even saponite-stevensite [111]. Maybe the disagreement is a consequence of the difficulty in obtaining accurate structural formulae because of the high magnesium content of the samples and the possibility that this cation is both in the octahedral sheet and in the interlayer. This makes the structural formulae harder to properly fit due to the complexity of discriminating how much $\mathrm{Mg}$ is an octahedral cation and how much is an exchangeable cation. In addition, some previous works found scarce Li and Sr as interlayer cations in the Pink Clays. 
Table 3. Chemical composition of individual particles obtained by point analyses in analytical electron microscopy (AEM) and structural formulae of the studied samples obtained from the means of the chemical analyses acquired. M: mean, SD: standard deviation, $n$ : number of analyses.

\begin{tabular}{|c|c|c|c|c|c|c|c|c|c|c|c|c|c|c|c|c|c|c|c|c|c|c|c|}
\hline & & \multicolumn{8}{|c|}{ Mean of the Chemical Analyses } & \multicolumn{3}{|c|}{$\begin{array}{c}\text { Tetrahedral } \\
\text { Cations (TC) }\end{array}$} & \multicolumn{5}{|c|}{ Octahedral Cations (OC) } & \multicolumn{3}{|c|}{$\begin{array}{l}\text { Interlayer Cations } \\
\text { (IC) }\end{array}$} & \multirow[b]{2}{*}{ TC } & \multirow[b]{2}{*}{ OC } & \multirow[b]{2}{*}{ IC } \\
\hline & & $\mathrm{SiO}_{2}$ & $\mathrm{Al}_{2} \mathrm{O}_{3}$ & $\mathrm{Fe}_{2} \mathrm{O}_{3}$ & $\mathrm{TiO}_{2}$ & $\mathrm{MgO}$ & $\mathrm{CaO}$ & $\mathrm{NaO}$ & $\mathrm{K}_{2} \mathrm{O}$ & Si & $\mathrm{Al}^{\mathrm{IV}}$ & $\mathrm{Fe}^{3+}$ & $\mathrm{Al}^{\mathrm{VI}}$ & $\mathrm{Fe}^{3+}$ & $\mathrm{Mg}$ & $\mathrm{Ti}$ & $\Sigma \mathbf{o}$ & $\mathrm{Ca}$ & K & $\mathrm{Na}$ & & & \\
\hline \multirow{2}{*}{$\begin{array}{c}\text { ESB } 2 \\
n: 18\end{array}$} & M & 60.62 & 7.82 & 4.44 & & 26.19 & 0.48 & & 0.46 & 7.43 & 0.57 & & 0.56 & 0.41 & 4.78 & & 5.75 & 0.02 & 0.07 & & -0.57 & 0.47 & 0.11 \\
\hline & SD & 2.29 & 4.57 & 3.43 & & 5.52 & 0.23 & & 0.67 & & & & & & & & & & & & & & \\
\hline \multirow{2}{*}{$\begin{array}{l}\text { ESB } 3 \\
n: 19 \\
\end{array}$} & $\mathrm{M}$ & 63.23 & 8.19 & 3.59 & & 23.86 & 0.52 & 0.04 & 0.56 & 7.66 & 0.34 & & 0.83 & 0.33 & 4.31 & & 5.47 & 0.07 & 0.09 & 0.01 & -0.34 & 0.10 & 0.24 \\
\hline & SD & 1.94 & 3.27 & 4.59 & & 5.14 & 0.16 & 0.38 & 0.36 & & & & & & & & & & & & & & \\
\hline \multirow{2}{*}{$\begin{array}{l}\text { ESB } 6 \\
n: 14\end{array}$} & M & 61.91 & 12.27 & 2.71 & & 20.89 & 0.84 & 0.10 & 1.28 & 7.50 & 0.50 & & 1.25 & 0.25 & 3.77 & & 5.27 & 0.11 & 0.20 & 0.02 & -0.49 & 0.04 & 0.44 \\
\hline & $\mathrm{SD}$ & 2.38 & 4.25 & 1.11 & & 3.89 & 0.70 & 0.12 & 0.91 & & & & & & & & & & & & & & \\
\hline \multirow{2}{*}{$\begin{array}{c}\text { ESB } 45 \\
n: 36\end{array}$} & $\mathrm{M}$ & 66.16 & 5.51 & 1.19 & & 26.32 & 0.39 & & 0.36 & 7.94 & 0.06 & & 0.72 & 0.11 & 4.71 & & 5.54 & 0.05 & 0.06 & & -0.06 & -0.09 & 0.16 \\
\hline & $\mathrm{SD}$ & 3.48 & 4.01 & 1.46 & & 4.24 & 0.19 & & 0.62 & & & & & & & & & & & & & & \\
\hline \multirow{2}{*}{$\begin{array}{l}\mathrm{MCM} \\
n: 19\end{array}$} & $\mathrm{M}$ & 59.91 & 5.91 & 1.70 & & 30.96 & 0.50 & 0.24 & 0.76 & 7.34 & 0.66 & & 0.19 & 0.16 & 5.65 & & 6.00 & 0.07 & 0.12 & 0.06 & -0.66 & 0.35 & 0.32 \\
\hline & SD & 1.80 & 1.08 & 0.61 & & 1.59 & 0.20 & 0.70 & 1.31 & & & & & & & & & & & & & & \\
\hline \multirow{2}{*}{$\begin{array}{l}\text { PB } 10 \\
n: 14\end{array}$} & $\mathrm{M}$ & 61.30 & 6.02 & 2.85 & 0.08 & 28.17 & 1.02 & & 0.55 & 7.46 & 0.54 & & 0.32 & 0.26 & 5.21 & 0.01 & 5.80 & 0.13 & 0.09 & & -0.54 & 0.16 & 0.35 \\
\hline & SD & 2.93 & 3.50 & 1.99 & 0.18 & 3.50 & 0.40 & & 0.74 & & & & & & & & & & & & & & \\
\hline \multirow{2}{*}{$\begin{array}{l}\text { PB } 11 \\
n: 19\end{array}$} & $\mathrm{M}$ & 59.09 & 11.22 & 5.42 & 0.20 & 21.88 & 0.51 & 0.02 & 1.67 & 7.28 & 0.72 & & 0.91 & 0.50 & 4.02 & 0.02 & 5.43 & 0.07 & 0.26 & & -0.72 & 0.27 & 0.40 \\
\hline & SD & 2.94 & 6.84 & 2.90 & 0.47 & 7.42 & 0.21 & 0.08 & 1.31 & & & & & & & & & & & & & & \\
\hline \multirow{2}{*}{$\begin{array}{l}\text { VER } \\
n: 39 \\
\end{array}$} & $\mathrm{M}$ & 57.99 & 18.99 & 6.65 & & 14.27 & 0.42 & & 1.65 & 7.09 & 0.91 & & 1.83 & 0.61 & 2.60 & & 5.04 & 0.06 & 0.26 & & -0.91 & 0.52 & 0.38 \\
\hline & SD & 3.64 & 8.14 & 3.95 & & 8.82 & 0.64 & & 1.37 & & & & & & & & & & & & & & \\
\hline \multirow{2}{*}{$\begin{array}{l}\text { ROS } \\
n: 50\end{array}$} & M & 65.83 & 1.50 & 0.57 & & 31.55 & 0.44 & & 0.11 & 7.93 & 0.07 & & 0.14 & 0.05 & 5.67 & & 5.86 & 0.06 & 0.02 & & -0.07 & -0.09 & 0.14 \\
\hline & $\mathrm{SD}$ & 1.62 & 1.24 & 0.63 & & 2.40 & 0.27 & & 0.22 & & & & & & & & & & & & & & \\
\hline \multirow{2}{*}{$\begin{array}{l}\text { RESQ } \\
n: 76\end{array}$} & $\mathrm{M}$ & 63.90 & 1.30 & 0.40 & & 34.03 & 0.23 & 0.02 & 0.12 & 7.74 & 0.19 & 0.04 & & & 6.14 & & 6.14 & 0.03 & 0.02 & & -0.35 & 0.28 & 0.08 \\
\hline & SD & 1.45 & 1.66 & 0.21 & & 1.74 & 0.39 & 0.15 & 0.48 & & & & & & & & & & & & & & \\
\hline \multirow{2}{*}{$\begin{array}{l}\text { NAV } 5 \\
n: 11\end{array}$} & $\mathrm{M}$ & 60.32 & 31.50 & 2.97 & & 2.80 & 1.31 & & 1.09 & 7.14 & 0.86 & & 3.53 & 0.26 & 0.49 & & 4.28 & 0.17 & 0.16 & & -0.86 & 0.35 & 0.50 \\
\hline & SD & 3.42 & 4.41 & 1.86 & & 1.05 & 0.43 & & 0.59 & & & & & & & & & & & & & & \\
\hline \multirow{2}{*}{$\begin{array}{c}\text { NAV } 6 \\
n: 29\end{array}$} & $\mathrm{M}$ & 65.15 & 26.32 & 1.12 & & 4.72 & 2.50 & & 0.17 & 7.63 & 0.37 & & 3.26 & 0.10 & 0.82 & & 4.18 & 0.31 & 0.03 & & -0.37 & -0.28 & 0.65 \\
\hline & SD & 1.92 & 1.75 & 0.64 & & 0.93 & 0.90 & & 0.22 & & & & & & & & & & & & & & \\
\hline \multirow{2}{*}{$\begin{array}{c}\text { RodF17 } \\
n: 14\end{array}$} & $\mathrm{M}$ & 64.35 & 23.88 & 2.85 & & 5.14 & 2.76 & & 1.02 & 7.64 & 0.36 & & 2.98 & 0.25 & 0.91 & & 4.14 & 0.35 & 0.15 & & -0.36 & -0.49 & 0.85 \\
\hline & SD & 3.19 & 3.94 & 1.46 & & 1.15 & 1.92 & & 0.82 & & & & & & & & & & & & & & \\
\hline \multirow{2}{*}{$\begin{array}{c}\text { CarbF11 } \\
n: 19\end{array}$} & $\mathrm{M}$ & 65.92 & 21.30 & 4.32 & & 5.18 & 2.42 & & 0.87 & 7.83 & 0.17 & & 2.81 & 0.39 & 0.92 & & 4.12 & 0.31 & 0.13 & & -0.17 & -0.56 & 0.75 \\
\hline & SD & 2.46 & 1.85 & 1.81 & & 0.90 & 0.61 & & 0.61 & & & & & & & & & & & & & & \\
\hline
\end{tabular}


Table 3. Cont

\begin{tabular}{|c|c|c|c|c|c|c|c|c|c|c|c|c|c|c|c|c|c|c|c|c|c|c|}
\hline & & \multicolumn{7}{|c|}{ Mean of the Chemical Analyses } & \multicolumn{3}{|c|}{$\begin{array}{l}\text { Tetrahedral } \\
\text { Cations (TC) }\end{array}$} & \multicolumn{5}{|c|}{ Octahedral Cations (OC) } & \multicolumn{3}{|c|}{$\begin{array}{l}\text { Interlayer Cations } \\
\text { (IC) }\end{array}$} & \multirow[b]{2}{*}{ TC } & \multirow[b]{2}{*}{ OC } & \multirow[b]{2}{*}{ IC } \\
\hline & & $\mathrm{SiO}_{2}$ & $\mathrm{Al}_{2} \mathrm{O}_{3}$ & $\mathrm{Fe}_{2} \mathrm{O}_{3} \quad \mathrm{TiO}_{2}$ & $\mathrm{MgO}$ & $\mathrm{CaO}$ & $\mathrm{NaO}$ & $\mathrm{K}_{2} \mathrm{O}$ & Si & $\mathrm{Al}^{\mathrm{IV}}$ & $\mathrm{Fe}^{3+}$ & $\mathrm{Al}^{\mathrm{VI}}$ & $\mathrm{Fe}^{3+}$ & Mg & Ti & $\Sigma \mathbf{o}$ & $\mathrm{Ca}$ & K & $\mathrm{Na}$ & & & \\
\hline \multirow{2}{*}{$\begin{array}{l}\text { CAR } 1 \\
n: 42\end{array}$} & $\mathrm{M}$ & 65.58 & 22.45 & 3.83 & 6.38 & 1.02 & 0.26 & 0.48 & 7.74 & 0.26 & & 2.86 & 0.34 & 1.12 & & 4.32 & 0.13 & 0.07 & 0.06 & -0.26 & -0.15 & 0.39 \\
\hline & SD & 1.25 & 1.16 & 1.68 & 0.93 & 0.30 & 0.38 & 0.40 & & & & & & & & & & & & & & \\
\hline \multirow{2}{*}{$\begin{array}{l}\text { CAR } 2 \\
n: 27\end{array}$} & $\mathrm{M}$ & 67.89 & 19.97 & 5.26 & 5.53 & 0.87 & & 0.55 & 8.01 & & & 2.78 & 0.47 & 0.97 & & 4.22 & 0.11 & 0.08 & & 0.04 & -0.32 & 0.30 \\
\hline & SD & 0.92 & 1.82 & 2.27 & 0.49 & 0.21 & & 0.53 & & & & & & & & & & & & & & \\
\hline \multirow{2}{*}{$\begin{array}{l}\text { CAR } 3 \\
n: 27\end{array}$} & $\mathrm{M}$ & 65.48 & 21.02 & 4.39 & 6.95 & 1.39 & 0.44 & 0.33 & 7.76 & 0.24 & & 2.70 & 0.39 & 1.23 & & 4.32 & 0.18 & 0.05 & 0.10 & -0.24 & -0.27 & 0.51 \\
\hline & SD & 1.05 & 0.74 & 1.41 & 0.37 & 0.24 & 0.33 & 0.14 & & & & & & & & & & & & & & \\
\hline \multirow{2}{*}{$\begin{array}{l}\text { LTBB } \\
n: 28\end{array}$} & $\mathrm{M}$ & 65.74 & 25.68 & 2.36 & 4.88 & 1.17 & 0.09 & 0.08 & 7.68 & 0.32 & & 3.22 & 0.21 & 0.85 & & 4.28 & 0.15 & 0.01 & 0.02 & -0.32 & -0.02 & 0.33 \\
\hline & SD & 2.48 & 2.95 & 1.19 & 1.19 & 0.96 & 1.21 & 0.21 & & & & & & & & & & & & & & \\
\hline \multirow{2}{*}{$\begin{array}{l}\text { LTBV } \\
n: 19\end{array}$} & $\mathrm{M}$ & 66.42 & 22.24 & 2.28 & 6.87 & 1.66 & 0.04 & 0.48 & 7.81 & 0.19 & & 2.89 & 0.20 & 1.20 & & 4.29 & 0.21 & 0.07 & 0.01 & -0.19 & -0.33 & 0.50 \\
\hline & SD & 1.81 & 2.55 & 1.62 & 1.81 & 0.35 & 0.23 & 0.88 & & & & & & & & & & & & & & \\
\hline \multirow{2}{*}{$\begin{array}{l}\text { LTBN } \\
n: 26\end{array}$} & M & 65.60 & 21.59 & 4.79 & 7.06 & 0.74 & 0.09 & 0.14 & 7.75 & 0.25 & & 2.76 & 0.43 & 1.24 & & 4.43 & 0.09 & 0.02 & 0.02 & -0.25 & 0.05 & 0.22 \\
\hline & SD & 2.73 & 1.65 & 4.46 & 0.98 & 0.20 & 0.17 & 0.09 & & & & & & & & & & & & & & \\
\hline \multirow{2}{*}{$\begin{array}{l}\text { MM } \\
n: 19\end{array}$} & $\mathrm{M}$ & 65.04 & 17.18 & 8.07 & 7.83 & 0.97 & 0.17 & 0.72 & 7.82 & 0.18 & & 2.26 & 0.73 & 1.40 & & 4.39 & 0.13 & 0.11 & 0.04 & -0.18 & -0.23 & 0.41 \\
\hline & SD & 4.47 & 3.06 & 5.72 & 2.37 & 0.69 & 0.38 & 0.42 & & & & & & & & & & & & & & \\
\hline
\end{tabular}


In agreement with bibliographic data (Table 4), the samples that had the lowest charge layer and the highest number of octahedral cations, i.e., those that had chemical compositions closer to kerolite, were the Pink Clay samples, while smectites from the Green Clay samples had compositions closer to saponite. In addition, as shown by the XRD patterns, the Green Clays had higher impurity contents (illite, quartz, and feldspar), while the Pink Clay samples usually were pure smectite, almost devoid of other minor minerals. This is related to the inherited character of the Green Clays versus the autigenic origin of the Pink Clays formed in the sedimentary basin, as indicated by Garcia-Rivas et al. [77].

Some trioctahedral samples from the Tajo Basin (ESB 2, ESB 3, ESB 6, MCM, PB 10, PB 11, VER, and RESQ), but also a dioctahedral sample from Tamame de Sayago (NAV 5), had an excess octahedral charge instead of having a deficit, as should be expected. This erroneousness was especially remarkable in samples VER (0.52), ESB 2 (0.47) MCM (0.35), NAV 5 (0.35), RESQ (0.28), and PB 11 (0.27) (Table 3). The positive octahedral charge in saponite could have been a consequence of the erroneous assignment of all the Mg to the octahedral layer instead of it being distributed both in the octahedral position and in the interlayer, as has been pointed out previously. This is a common error (as was possibly observed in Reference [112,113]) that happens when the structural formulae of samples that have $\mathrm{Mg}$ are calculated, since it is generally assumed that $\mathrm{Mg}$ has to be assigned to the octahedral position, obviating its presence as an interlayer cation. The more interlayer $\mathrm{Mg}$ contained in the sample, the higher the error in the formula can be. In agreement with this explanation was the low charge of the layer obtained for most magnesic samples. Furthermore, if the sample had $\mathrm{K}$ as an interlayer cation, as happened in samples PB 11, VER, and NAV 5, the excess octahedral charge could be explained as a scarce amount of mica layers interstratified within the smectite crystals.

On the other hand, smectites from Tamame de Sayago, according to the structural formulae obtained in this work (Table 3) as well as to those obtained in previous studies (Table 4), are dioctahedral both if they are smectites formed by the transformation of pre-existing minerals (kaolinite and micas) and if they are formed by neoformation or direct precipitation from hydrothermal solutions. Contrarily to the Tajo smectites, the Tamame de Sayago smectites had high $\mathrm{Al}_{2} \mathrm{O}_{3}$ contents (21.3\% to 31.5\%) and very low $\mathrm{MgO}$ (2.8\% to 5.18\%). They also had low $\mathrm{Fe}_{2} \mathrm{O}_{3}$ amounts corresponding to very white samples. The number of octahedral cations were close to 4 (4.12-4.28), and the layer charge varied from 0.5 to 0.85 . They could be classified as corresponding to montmorillonite-beidellite series. Although the compositional variation between the samples was low, they showed a continuous compositional variation between both end terms. The smectites that came from the kaolinitized granite alteration were beidellites, and as the alteration degree rose, the more montmorillonitic the smectites were. In the same way, the smectites from the veins were montmorillonites. The smectites that appeared in the Tertiary cover were intermediate (between montmorillonite and beidellite, according to Manchado) [86]. Summarizing, the farther from the faults the formed smectites were, the less hydrothermal fluids affected the rock, and the smectites were closer to beidellite. On the other hand, the closer they were to the faults, the higher the influence of the hydrothermal fluids was, and consequently, the smectites were more montmorillonitic. 
Table 4. Structural formulae of Spanish bentonites taken from previous works. REF: number of references. X+: interlayer charge. Analyses with “*” were done by AEM, and analyses without "**" were done from whole rock.

\begin{tabular}{|c|c|c|c|c|c|c|c|c|c|c|c|c|c|}
\hline & & \multirow{2}{*}{ Ref. } & \multicolumn{2}{|c|}{ Tetrahedral Cations } & \multicolumn{4}{|c|}{ Octahedral Cations } & \multirow[b]{2}{*}{$\Sigma \mathbf{o}$} & \multicolumn{4}{|c|}{ Interlayer Cations } \\
\hline & & & Si & $\mathrm{Al}^{\mathrm{IV}}$ & $\mathrm{Al}^{\mathrm{VI}}$ & $\mathrm{Fe}^{3+}$ & $\mathrm{Mg}$ & $\mathrm{Ti}$ & & $\mathrm{Ca}$ & $\mathrm{K}$ & $\mathrm{Na}$ & $\mathrm{X}^{+}$ \\
\hline \multirow{25}{*}{$\begin{array}{l}\text { Tajo } \\
\text { Basin }\end{array}$} & \multirow{13}{*}{$\begin{array}{l}\text { Green } \\
\text { Clays }\end{array}$} & {$[67]^{*}$} & 7.40 & 0.60 & 0.40 & 0.05 & 5.40 & & 5.85 & & & & 0.30 \\
\hline & & {$[71]^{*}$} & 7.52 & 0.48 & 0.88 & 0.52 & 3.62 & & 5.02 & 0.10 & 0.38 & & \\
\hline & & {$[71]^{*}$} & 6.18 & 1.80 & 3.58 & 0.16 & 0.46 & & 4.20 & & 1.58 & & \\
\hline & & {$[71]^{*}$} & 6.70 & 1.30 & 1.10 & 0.46 & 3.62 & & 5.18 & 0.06 & 0.50 & & \\
\hline & & {$[25]$} & 7.33 & 0.67 & 0.33 & 0.25 & 5.00 & 0.02 & 5.60 & 0.40 & 0.05 & & \\
\hline & & [25] & 7.26 & 0.74 & 0.52 & 0.35 & 4.55 & 0.03 & 5.45 & 0.39 & 0.13 & & \\
\hline & & [114] & 7.44 & 0.56 & 0.54 & 0.26 & 4.64 & & 5.44 & & 0.04 & & 0.41 \\
\hline & & [115] & 7.60 & 0.40 & 0.30 & 0.24 & 4.60 & & 5.14 & & 0.15 & & 0.29 \\
\hline & & [115] & 7.54 & 0.46 & 0.26 & 0.18 & 5.20 & & 5.64 & & 0.04 & & 0.33 \\
\hline & & [28] & 7.53 & 0.47 & 0.19 & 0.15 & 5.29 & 0.02 & 5.65 & 0.03 & & 0.04 & \\
\hline & & [28] & 7.68 & 0.32 & 0.13 & & 5.68 & 0.01 & 5.82 & 0.01 & & 0.04 & \\
\hline & & [75] & 7.00 & 1.00 & 0.18 & & 5.92 & & 6.10 & 0.12 & 0.03 & & \\
\hline & & [75] & 6.40 & 1.60 & 0.88 & 0.82 & 3.68 & 0.1 & 5.48 & 0.18 & 0.46 & & \\
\hline & \multirow{12}{*}{$\begin{array}{l}\text { Pink } \\
\text { Clays }\end{array}$} & [78] & 8.01 & & 0.36 & 0.11 & 4.76 & & 5.26 & & 0.01 & 0.01 & \\
\hline & & [25] & 7.69 & 0.31 & 0.09 & 0.08 & 5.61 & & 5.78 & 0.29 & 0.01 & & \\
\hline & & [28] & 7.88 & 0.12 & 0.02 & 0.03 & 5.88 & 0.01 & 5.93 & & & 0.02 & \\
\hline & & [28] & 8.00 & & 0.10 & 0.05 & 5.66 & & 5.81 & 0.04 & & 0.04 & \\
\hline & & [28] & 7.90 & 0.10 & 0.03 & 0.03 & 5.89 & 0.01 & 5.95 & 0.02 & & 0.01 & \\
\hline & & [28] & 8.00 & & 0.10 & 0.05 & 5.66 & & 5.81 & 0.04 & 0.01 & 0.04 & \\
\hline & & [28] & 7.90 & 0.10 & 0.03 & 0.03 & 5.89 & 0.01 & 5.96 & 0.02 & & 0.01 & \\
\hline & & [75] & 7.98 & 0.02 & 0.64 & 0.06 & 4.80 & & 5.50 & 0.07 & 0.04 & & \\
\hline & & [109] & 8.00 & & 0.13 & 0.05 & 5.60 & & 5.78 & 0.08 & 0.06 & 0.04 & \\
\hline & & [111] & 7.94 & 0.06 & 0.15 & 0.09 & 5.34 & 0.01 & 5.58 & 0.18 & 0.01 & 0.08 & \\
\hline & & [111] & 7.51 & 0.49 & 0.43 & 0.16 & 4.95 & 0.01 & 5.54 & 0.35 & 0.08 & & \\
\hline & & [28] & 7.80 & 0.20 & 0.06 & 0.06 & 5.56 & 0.01 & 5.68 & & 0.02 & 0.06 & \\
\hline
\end{tabular}


Table 4. Cont.

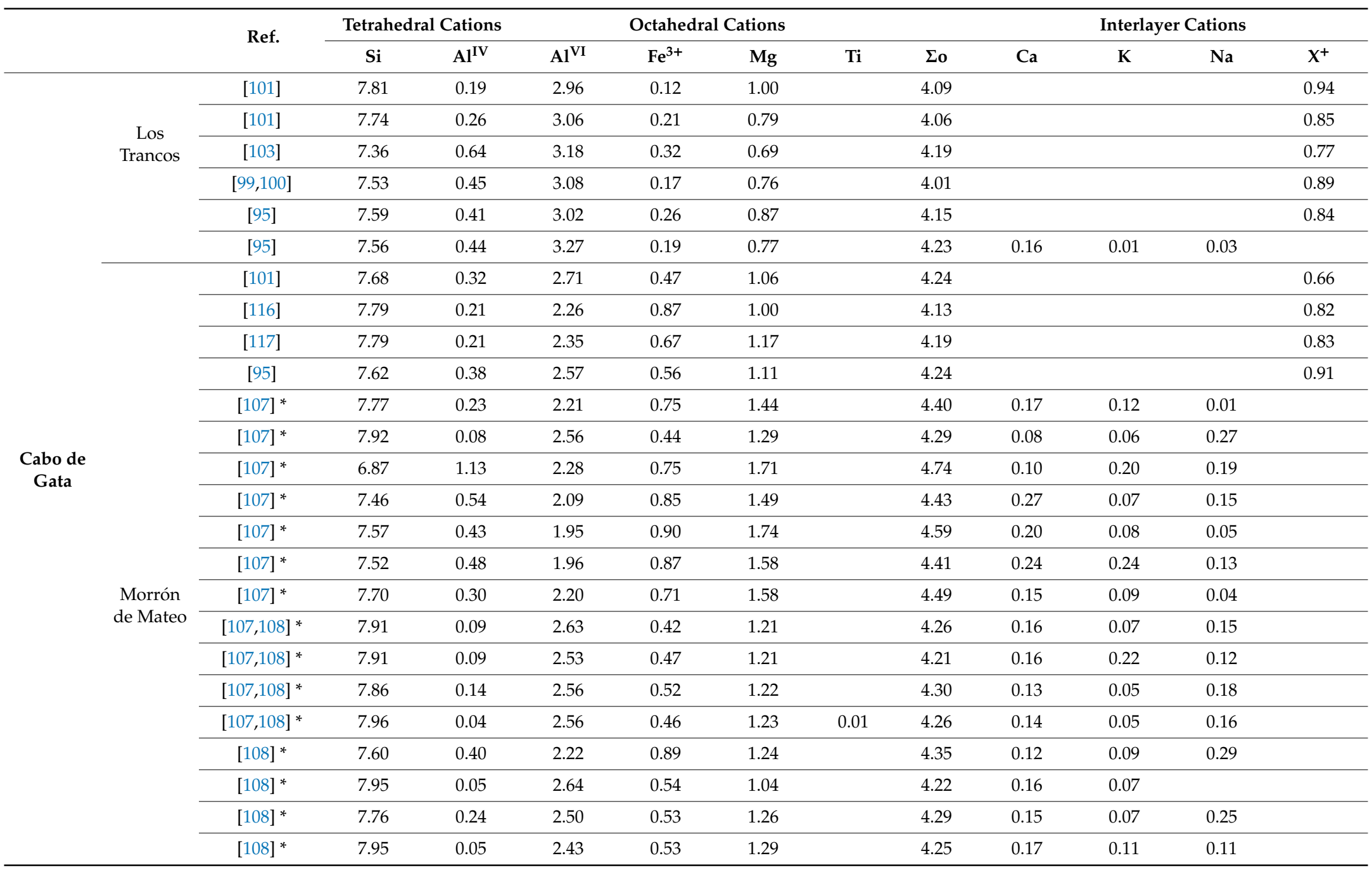


Table 4. Cont.

\begin{tabular}{|c|c|c|c|c|c|c|c|c|c|c|c|c|c|}
\hline & & \multirow{2}{*}{ Ref. } & \multicolumn{2}{|c|}{ Tetrahedral Cations } & \multicolumn{4}{|c|}{ Octahedral Cations } & \multirow[b]{2}{*}{$\Sigma \mathbf{o}$} & \multicolumn{4}{|c|}{ Interlayer Cations } \\
\hline & & & $\mathrm{Si}$ & $\mathrm{Al}^{\mathrm{IV}}$ & $\mathrm{Al}^{\mathrm{VI}}$ & $\mathrm{Fe}^{3+}$ & $\mathrm{Mg}$ & $\mathrm{Ti}$ & & $\mathrm{Ca}$ & $\mathbf{K}$ & $\mathrm{Na}$ & $\mathrm{X}^{+}$ \\
\hline \multirow{12}{*}{\multicolumn{2}{|c|}{$\begin{array}{c}\text { Cabo de } \\
\text { Gata }\end{array}$}} & {$[108]^{*}$} & 7.78 & 0.22 & 2.41 & 0.53 & 1.34 & & 4.28 & 0.17 & 0.07 & 0.30 & \\
\hline & & {$[108]^{*}$} & 7.65 & 0.35 & 2.31 & 0.71 & 1.26 & & 4.28 & 0.08 & 0.21 & 0.38 & \\
\hline & & {$[108]^{*}$} & 7.83 & 0.17 & 2.26 & 0.80 & 1.19 & 0.03 & 4.28 & 0.11 & 0.11 & 0.19 & \\
\hline & & {$[108]^{*}$} & 7.77 & 0.23 & 2.47 & 0.63 & 1.18 & & 4.28 & 0.17 & 0.14 & 0.20 & \\
\hline & & {$[108]^{*}$} & 7.80 & 0.20 & 2.66 & 0.53 & 1.09 & 0.01 & 4.29 & 0.12 & 0.10 & 0.07 & \\
\hline & & {$[108]^{*}$} & 7.48 & 0.52 & 2.61 & 0.65 & 1.06 & 0.01 & 4.33 & 0.12 & 0.12 & 0.19 & \\
\hline & & {$[108]^{*}$} & 7.73 & 0.27 & 2.43 & 0.65 & 1.20 & & 4.28 & 0.18 & 0.11 & 0.14 & \\
\hline & & {$[108]^{*}$} & 7.72 & 0.28 & 2.32 & 0.72 & 1.22 & & 4.26 & 0.19 & 0.12 & 0.23 & \\
\hline & & {$[108]^{*}$} & 7.81 & 0.19 & 2.42 & 0.65 & 1.17 & 0.01 & 4.25 & 0.12 & 0.13 & 0.24 & \\
\hline & & {$[108]^{*}$} & 7.03 & 0.97 & 0.77 & 1.54 & 2.76 & 0.02 & 5.09 & 0.10 & & 0.26 & \\
\hline & & {$[108]^{*}$} & 7.01 & 0.99 & 0.82 & 1.51 & 2.59 & & 4.92 & 0.08 & 0.11 & 0.58 & \\
\hline & & {$[108]^{*}$} & 6.61 & 1.39 & 0.91 & 1.53 & 2.78 & & 5.22 & 0.14 & 0.02 & 0.20 & \\
\hline \multirow{4}{*}{\multicolumn{2}{|c|}{$\begin{array}{l}\text { Cortijo } \\
\text { Archidona }\end{array}$}} & [101] & 7.74 & 0.26 & 2.69 & 0.55 & 1.04 & & 4.28 & & & & 0.74 \\
\hline & & [95] & 7.77 & 0.22 & 2.78 & 0.33 & 1.03 & & 4.14 & & & & 0.81 \\
\hline & & {$[118]^{*}$} & 8.00 & & 2.68 & 0.56 & 0.89 & & 4.13 & & & & \\
\hline & & [119] & 7.71 & 0.22 & 2.73 & 0.52 & 0.86 & & 4.11 & 0.11 & & & 0.83 \\
\hline \multirow{4}{*}{\multicolumn{2}{|c|}{ Tamame }} & {$[86]^{*}$} & 6.64 & 1.36 & 4.07 & 0.29 & & & 4.36 & 0.09 & 0.10 & & \\
\hline & & {$[86]^{*}$} & 7.63 & 0.37 & 3.23 & 0.17 & 0.79 & & 4.19 & 0.26 & 0.07 & & \\
\hline & & {$[86]^{*}$} & 7.74 & 0.26 & 3.12 & 0.21 & 0.77 & & 4.10 & 0.30 & 0.07 & 0.03 & \\
\hline & & {$[86]^{*}$} & 7.58 & 0.42 & 3.07 & 0.23 & 0.88 & & 4.18 & 0.32 & 0.11 & & \\
\hline
\end{tabular}


The smectites from the Cabo de Gata deposits were also dioctahedral. The compositions of the samples from the three studied deposits were quite similar and varied in a narrow range. The structural formulae calculated from the mean values of the point analyses obtained by AEM are listed in Table 3. In agreement with the bibliographic data (Table 4), the analyses of smectites from Cortijo de Archidona and Los Trancos showed a continuous compositional variation between beidellite-montmorillonite series, while the samples from Morrón de Mateo were montmorillonites. The $\mathrm{Al}_{2} \mathrm{O}_{3}$ content was high (Cortijo de Archidona: 19.97-22.45\%; Los Trancos: 21.59-25.68\%; Morrón de Mateo: 17.18\%), and the $\mathrm{MgO}$ content was low (Cortijo de Archidona: 5.53-6.95\%, Los Trancos: 4.88-7.06\%; Morrón de Mateo: $7.83 \%$ ), corresponding to dioctahedral smectites. The layer charge was low, since it varied from 0.22 to 0.51 , and the number of octahedral cations ranged from 4.22 to 4.43 per unit cell. In the Morrón de Mateo deposit, there is continuous compositional variation between $\mathrm{Al}$ montmorillonites and Fe-Mg-rich saponites as a consequence of the intrusion of the volcanic dome, according to Pelayo et al. [108].

The structural formulae of the smectites analyzed in this work (Table 3) and those that came from the bibliography (Table 4) are plotted in a ternary plot (Figure 12) in which the proportions of the main cations $(\mathrm{Si}, \mathrm{Al}+\mathrm{Fe}$, and $\mathrm{Mg}$ ) are considered. There was a clear difference between the dioctahedral smectites from Cabo de Gata and Tamame de Sayago and the trioctahedral smectites from the Tajo basin, but inside each group there were no remarkable differences between the bibliography data and the new data here presented. Some points corresponding to Green Clays, both in these results and in the bibliography showed a certain intermediate character, between dioctahedral and trioctahedral, and they are plotted in the middle of the trend. All of the dioctahedral smectites plotted were richer in Si than the trioctahedral smectites were (both Pink Clays and Green Clays), and therefore they are plotted closer to the Si vertex. The smectites from Tamame, Los Trancos, and Cortijo de Archidona were much more grouped, showing a higher content of $\mathrm{Al}+\mathrm{Fe}^{3+}$ than those from Morrón de Mateo did.

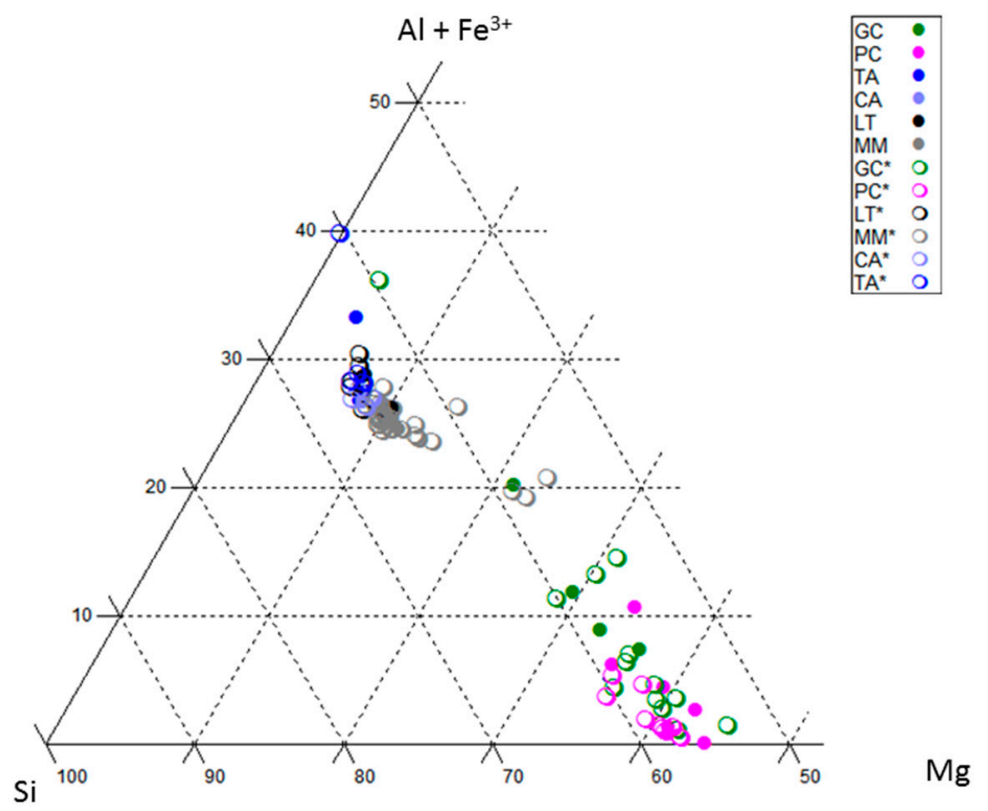

Figure 12. Ternary plot showing the proportions of $\mathrm{Si}$ and octahedral cations $\left(\mathrm{Al}+\mathrm{Fe}^{3+}\right.$ and $\left.\mathrm{Mg}\right)$ from the structural formulae of both the smectites analyzed in this work (Table 3) and those from bibliography data (Table 4). GC: Green Clays; PC: Pink Clays. Samples from Table 3: TA, Tamame; CA, Cortijo de Archidona; LT, Los Trancos; MM, Morrón de Mateo. Samples from Table 4 have the same labels (with *). 
Supplementary Materials: The following are available online at http://www.mdpi.com/2075-163X/9/11/696/s1, Figure S1: XRD-patterns of sample ROS, Table S1: Correlation matrix of major oxides, Table S2. Content of minor and trace elements in Spanish bentonites.

Author Contributions: All the authors have equally contributed in the obtention of the data, their treatment, discussion and in the elaboration of the research paper and conclusions here presented.

Funding: The financial support for this work was provided by MINECO (CGL2016-77005-R).

Acknowledgments: Javier García-Rivas would like to thank the FCT (Portuguese Science and Technology Foundation) for project UID/Multi/04349/2019 and postdoctoral fellowship BL224/2018_IST-ID at the C2TN.

Conflicts of Interest: The authors declare no conflict of interest.

\section{References}

1. Álvarez, A.; Santarén, J.; Esteban-Cubillo, A.; Aparicio, P. Current Industrial Applications of Palygorskite and Sepiolite. Dev. Clay Sci. 2011, 3, 281-298.

2. Harvey, C.C.; Lagaly, G. Industrial Applications. In Developments in Clay Science; Elsevier: Amsterdam, The Netherlands, 2013; Volume 5, pp. 451-490.

3. Babu Valapa, R.; Loganathan, S.; Pugazhenthi, G.; Thomas, S.; Varghese, T.O. An Overview of Polymer-Clay Nanocomposites. In Clay-Polymer Nanocomposites; Elsevier: Amsterdam, The Netherlands, 2017; pp. $29-81$.

4. Mohanty, F.; Swain, S.K. Bionanocomposites for Food Packaging Applications. In Nanotechnology Applications in Food: Flavor, Stability Nutrition and Safety; Academic Press: Cambridge, MA, USA, 2017; pp. 363-379.

5. Rebitski, E.P.; Souza, G.P.; Santana, S.A.A.; Pergher, S.B.C.; Alcântara, A.C.S. Bionanocomposites based on cationic and anionic layered clays as controlled release devices of amoxicillin. Appl. Clay Sci. 2019, 173, $35-45$. [CrossRef]

6. Lee, S.M.; Tiwari, D. Organo and inorgano-organo-modified clays in the remediation of aqueous solutions: An overview. Appl. Clay Sci. 2012, 59-60, 84-102. [CrossRef]

7. De Brito, B.M.A.; Cartaxo, J.M.; Costa, J.M.R.; Ferreira, H.C.; Neves, G.A. Comparative study of organoclays with ionic surfactant. Mater. Sci. Forum 2014, 798-799, 9-14. [CrossRef]

8. Singh, P.P.; Ambika, B. Bentonite: A Versatile Clay. In Bentonite: Characteristics, Uses and Implications for the Environment; Mishra, A.K., Ed.; Nova Science Pb. Inc.: London, UK, 2015; pp. 151-172.

9. Jones, B.F. Clay mineral diagenesis in lacustrine sediments. US Geol. Surv. Bull. 1986, 1578, 291-300.

10. Darragi, F.; Tardy, Y. Authigenic trioctahedral smectites controlling $\mathrm{pH}$, alkalinity, silica an Mg-concentrations in alkaline lakes. Chem. Geol. 1987, 63, 59-72. [CrossRef]

11. Hay, R.L.; Pexton, R.E.; Teague, T.T.; Kyser, T.K. Spring-related carbonate rocks, Mg clays, and associated minerals in Pliocene deposits of the Amargosa Desert, Nevada and California. Geol. Soc. Am. Bull. 1986, 97, 1488-1503. [CrossRef]

12. Fiore, S.; Huertas, F.J.; Huertas, F.; Linares, J. Smectite formation in rhyolitic obsidian as inferred by microscopic (SEM-TEM-AEM) investigation. Clay Miner. 2001, 36, 489-500. [CrossRef]

13. Birsoy, R. Formation of sepiolite-palygorskite and related minerals from solution. Clays Clay Miner. 2002, 50, 736-745. [CrossRef]

14. Furquim, S.A.C.; Graham, R.C.; Barbiero, L.; Neto, J.P.D.; Valles, V. Mineralogy and genesis of smectites in an alkaline-saline environment of Panatal Wetland, Brazil. Clays Clay Miner. 2008, 56, 579-595. [CrossRef]

15. Deocampo, D.M. Authigenic clay minerals in lacustrine mudstones. In Paying Attention to Mudrocks: Priceless; Egenhoff, S., Larsen, D., Fishman, N., Eds.; Geological Society of America Special Paper 515: Colorado, CO, USA, 2015; pp. 49-64.

16. Shimbashi, M.; Sato, T.; Yamakawa, M.; Fujii, N.; Otake, T. Formation of Fe- and Mg-Rich Smectite under Hyperalkaline Conditions at Narra in Palawan, the Philippines. Minerals 2018, 8, 155. [CrossRef]

17. Singer, A. Palygorskite in sediments: Detrital, diagenetic or neoformed-A critical review. Geol. Rundsch. 1979, 68, 996-1008. [CrossRef]

18. Ugolini, F.C. Hydrothermal origin of the clays from the upper slopes of Mauna Kea, Hawaii. Clays Clay Miner. 1974, 22, 189-194. [CrossRef]

19. Cann, J.R. Metamorphism in the ocean crust. In Maurice Ewing Series; Talwani, M., Harrison, C.G., Hayes, D.E., Eds.; American Geophysical Union: Washington, DC, USA, 1979; pp. 230-238. 
20. Thompson, G. Hydrothermal Fluxes in the Ocean. In Chemical Oceanography; Riley, J.P., Chester, R., Eds.; Elsevier: Amsterdam, The Netherlands, 1983; pp. 271-337.

21. Aoki, S.; Kohyama, N.; Hotta, H. Hydrothermal clay minerals found in sediment containing yellowish-brown material from the Japan Basin. Mar. Geol. 1996, 129, 331-336. [CrossRef]

22. Manuella, F.C.; Carbone, S.; Barreca, G. Origin of Saponite-Rich Clays in a Fossil Serpentinite-Hosted Hydrothermal System in the Crustal Basement of the Hyblean Plateau (Sicily, Italy). Clays Clay Miner. 2012, 60, 18-31. [CrossRef]

23. Khoury, H.N.; Eberl, D.D.; Jones, B.F. Origin of Magnesium Clays from the Amargosa Desert, Nevada. Clays Clay Miner. 1982, 30, 327-336. [CrossRef]

24. Bellanca, A.; Calvo, J.P.; Censi, P.; Neri, R.; Pozo, M. Recognition of lake-level changes in Miocene lacustrine units, Madrid Basin, Spain. Evidence from facies analysis, isotope geochemistry and clay mineralogy. Sediment. Geol. 1992, 76, 135-153. [CrossRef]

25. Cuevas, J.; Pelayo, M.; Rivas, P.; Leguey, S. Characterization of Mg-clays from the Neogene of the Madrid Basin and their potential as backfilling and sealing material in high level radioactive waste disposal. Appl. Clay Sci. 1993, 7, 383-406. [CrossRef]

26. Ece, Ö.İ.; Çoban, F. Geology, occurrence, and genesis of Eskişehir sepiolites, Turkey. Clays Clay Miner. 1994, 42, 81-92. [CrossRef]

27. Hay, R.L.; Hughes, R.E.; Kyser, T.K.; Glass, H.D.; Liu, J. Magnesium-Rich Clays of the Meerschaum Mines in the Amboseli Basin, Tanzania and Kenya. Clays Clay Miner. 1995, 43, 455-466. [CrossRef]

28. Pozo, M.; Casas, J. Origin of kerolite and associated Mg clays in palustrine-lacustrine environments. The Esquivias deposit (Neogene Madrid Basin, Spain). Clay Miner. 1999, 34, 395-418. [CrossRef]

29. Karakaya, M.Ç.; Karakaya, N.; Temel, A. Mineralogical and geochemical characteristics and genesis of the sepiolite deposits at Polatli Basin (Ankara, Turkey). Clays Clay Miner. 2011, 59, 286-314. [CrossRef]

30. Kadir, S.; Külah, T.; Önalgil, N.; Erkoyun, H.; Elliott, W.C. Mineralogy, Geochemistry, and Genesis of Bentonites in Miocene Volcanic-sedimentary Units of the Ankara-Çankiri Basin, Central Anatolia, Turkey. Clays Clay Miner. 2017, 65, 64-91. [CrossRef]

31. Pozo, M.; Calvo, J.P. An Overview of Authigenic Magnesian Clays. Minerals 2018, 8, 520. [CrossRef]

32. Mayayo, M.J.; Bauluz, B.; Lopez, J.M.G. Variations in the chemistry of smectites from the Calatayud Basin (NE Spain). Clay Miner. 2000, 35, 365-374. [CrossRef]

33. Harder, H. The role of magnesium in the formation of smectite minerals. Chem. Geol. 1972, 10, 31-39. [CrossRef]

34. Harder, H. Nontronite synthesis at low temperature. Chem. Geol. 1976, 18, 169-180. [CrossRef]

35. Harder, H. Synthesis if iron layer silicate minerals under natural conditions. Clays Clay Miner. 1978, 26, 65-72. [CrossRef]

36. Decarreau, A.; Bonnin, D. Synthesis and crystallogenesis at low temperature of Fe(II)-smectites by evolution of coprecipitated gels: Experiments in partial reducing conditions. Clay Miner. 1986, 21, 861-877. [CrossRef]

37. Decarreau, A.; Bonnin, D.; Badaut-Trauth, D.; Couty, R.; Kaiser, P. Synthesis and crystallogenesis of ferric smectites by evolution of Si-Fe coprecipitates in oxidizing conditions. Clay Miner. 1987, 22, 207-223. [CrossRef]

38. Masár, J.; Luptáková, V.; Kuchta, L.; Fajnor, V.S. Hydrothermal synthesis of montmorillonite containing iron in structure. Chem. Pap. 1987, 41, 343-350.

39. Kloprogge, J.T.; Jansen, J.B.H.; Geus, J.W. Characterization of synthetic Na-beidellite. Clays Clay Miner. 1990, 38, 409-414. [CrossRef]

40. Tomita, K.; Yamane, H.; Kawano, M. Synthesis of smectites from volcanic glass at low temperature. Clays Clay Miner. 1993, 41, 655-661. [CrossRef]

41. Huertas, F.J.; Cuadros, J.; Huertas, F.; Linares, J. Experimental study of the hydrothermal formation of smectite in the beidellite-saponite series. Am. J. Sci. 2000, 300, 504-527. [CrossRef]

42. Fesharaki, O.; García-Romero, E.; Cuevas-González, J.; López-Martínez, N. Clay mineral genesis evolution in the Miocene sediments of Somosaguas, Madrid Basin, Spain. Clay Miner. 2007, 42, 187-201. [CrossRef]

43. Cuadros, J.; Dekov, V.M.; Arroyo, X.; Nieto, F. Smectite formation in submarine hydrothermal sediments: Samples from the HMS Challenger expedition (1872-1876). Clays Clay Miner. 2011, 59, 147-164. [CrossRef]

44. Lacoviello, F.; Giorgetti, G.; Nieto, F.; Memmi, I.T. Evolution with depth from detrital to authigenic smectites in sediments from AND-2A drill core (McMurdo Sound, Antarctica). Clay Miner. 2012, 47, 481-498. [CrossRef] 
45. Christidis, G.E.; Dunham, A.C. Compositional Variations in Smectites. Part II: Alteration of Acidic Precursors. A Case Study from Milos Island, Greece. Clay Miner. 1997, 32, 253-270. [CrossRef]

46. García-Romero, E.; Vegas, J.; Baldonedo, J.L.; Marfil, R. Clay minerals as alteration products in basaltic volcaniclastic deposits of La Palma (Canary Islands, Spain). Sediment. Geol. 2005, 174, 237-253. [CrossRef]

47. Christidis, G.E. Genesis and compositional heterogeneity of smectites. Part III: Alteration of basic pyroclastic rocks-A case study from the Troodos Ophiolite Complex, Cyprus. Am. Mineral. 2006, 91, 685-701. [CrossRef]

48. Suarez, M.; Robert, M.; Elsass, F.; Martín-Pozas, J.M. Evidence of a precursor in the neoformation of palygorskite-New data by analytical electron microscopy. Clay Miner. 1994, 29, 255-264. [CrossRef]

49. Christidis, G.E. Formation and growth of smectites in bentonites: A case study from Kimolos Island, Aegean, Greece. Clays Clay Miner. 2001, 49, 204-215. [CrossRef]

50. Dias, M.I.; Suárez, M.; Prates, S. Las bentonitas de Benavila (Portugal). Caracterización mineralógica y propiedades. Geogaceta 2004, 35, 99-102.

51. Christidis, G.E.; Huff, W.D. Geological Aspects and Genesis of Bentonites. Elements 2009, 5, 93-98. [CrossRef]

52. Instituto Geológico y Minero de España (IGME). Panorama Minero; IGME: Madrid, Spain, 2019.

53. Hammer, Ø.; Harper, D.A.T.; Ryan, P.D. PAST. Paleontological Statistics Software Package for Education and Data Analysis. Palaeontol. Electron. 2001, 4, 9.

54. De Vicente, G.; Cloething, S.; Van Wees, J.D.; Cunha, P.P. Tectonic classification of Cenozoic Iberian foreland basins. Tectonohysics 2011, 502, 38-61. [CrossRef]

55. Calvo, J.P.; Jones, B.J.; Bustillo, M.A.; Fort, R.; Alonso-Zarza, A.M.; Kendall, C. Sedimentology and geochemistry of carbonates from lacustrine sequences in the Madrid Basin, Central Spain. Chem. Geol. 1995, 123, 173-191. [CrossRef]

56. Martín Escorza, C. Actividad Tectónica durante el Mioceno en las fracturas del basamento de la fosa del Tajo. Estud. Geol. 1976, 32, 509-522.

57. Alberdi, M.T.; Hoyos, M.; Junco, F.; López Martinez, N.; Morales, J.; Sese, C.; Soria, D. Bioiestratigraphie et évolution sedimentaire de l'aire de Madrid. Colloquium Mediterranean Neogene Continental Paleoenvironments and Paleoclimatic evolution. Monpellier 1983, 12-83.

58. Junco, F.; Calvo, J.P. Cuenca de Madrid. In Libro Jubilar JM Ríos; Instituto Geológico y Minero de España, Ríos, J.M., Eds.; Geologico y Minero de España: Madrid, Spain, 1983; pp. 534-542.

59. Mejías, A.G.; Ordoñez, S.; Calvo, J.P. Nuevas aportaciones al conocimiento geológico de la Cuenca de Madrid. Rev. Mater. Procesos Geol. 1983, 1, 163-191.

60. Portero, J.M.; Aznar, J.M. Evolución morfotectónica y sedimentación terciarias en el Sistema Central y Cuencas Limítrofes (Duero y Tajo). I Congr. Esp. Geol. 1984, 3, 147-153.

61. Torres, T.; Junco, F.; Zapata de La Vega, S.L.; Plaza, J.M. Similitud de los procesos sedimentarios del Neogeno de la cuenca del Tajo y en la Depresión intermedia. I Congr. Esp. Geol. 1984, 1, 285-300.

62. Calvo, J.P.; Ordoñez, S.; Hoyos, M.; García del Cura, M.A. Caracterización sedimentológica de la Unidad Intermedia del Mioceno de la zona Sur de Madrid Rev. Mater. Procesos Geol. 1984, 2, 145-176.

63. Calvo, J.P.; Alonso-Zarza, A.M.; García del Cura, M.A. Models of marginal lacustrine sedimentation in response to varied source areas in the Madrid Basin (Central Spain). Paleogeogr. Paleoclimatol. Paleoecol. 1989, 70, 199-214. [CrossRef]

64. Brell, J.M.; Doval, M.; Carames, M. Clay minerals distribution in the evaporitic Miocene sediments of the Tajo Basin, Spain. Mineral. Petrogr. Acta 1985, 29, 267-276.

65. Doval, M.; García Santiago, P.; Domínguez Díaz, M.C.; Brell, J.M. Mineralogía de las arcillas de las facies evaporíticas de la Cuenca del Tajo. Trab. Geol. 1985, 15, 267-274.

66. Doval, M.; Domínguez Díaz, M.C.; Brell, J.M.; García-Romero, E. Mineralogía y sedimentología de las facies distales del borde norte de la cuenca del Tajo. Bol. Soc. Esp. Mineral. 1985, 8, 257-269.

67. Galán, E.; Álvarez, A.; Esteban, M.A. Characterization and technical properties of a Mg-rich bentonite. Appl. Clay Sci. 1986, 1, 295-309. [CrossRef]

68. Garcia-Romero, E. Estudio Mineralógico y Estratigráfico de las Arcillas de las Facies Centrales del Neógeno del Borde sur de la Cuenca del Tajo. Ph.D. Thesis, Universidad complutense de Madrid, Madrid, Spain, 1988; p. 436. 
69. García-Romero, E.; Brell, J.M.; Doval, M.; Navarro, J.V. Caracterización mineralógica y estratigráfica de las formaciones neógenas del borde sur de la cuenca del Tajo (Comarca de la Sagra). Bol. Geol. Min. 1990, 101-106, 945-956.

70. Pozo, M.; Moreno, A.; Casas, J.; Martín Rubí, J.A. Estudio geoquímico de litofacies con arcillas magnésicas en depósitos lacutres-palustres de la Cuenca de Madrid. Bol. Soc. Esp. Mineral. 1996, 19, 71-83.

71. De Santiago, C.; Suárez, M.; Garcia Romero, E.; Domínguez Díaz, M.C.; Doval, M. Electron microscopic study of the illie-smectite transformation in the bentonites from Cerro del Águila (Toledo, Spain). Clay Miner. 1998, 33, 501-510.

72. García-Romero, E.; Bustillo, A.; Suarez, M. Characteristics of a Mg-palygorskite in Miocene rocks, Madrid basin (Spain). Clays Clay Miner. 2004, 52, 484-494.

73. Bustillo, M.A.; Alonso-Zarza, A.M. Overlapping of pedogenesis and meteoric diagenesis in distal alluvial and shallow lacustrine deposits in the Madrid Mioceno Basin, Spain. Sediment. Geol. 2007, 198, 255-271. [CrossRef]

74. García-Romero, E. Génesis de arcillas magnésicas en la cuenca de Madrid: Interrogantes planteados. Bol. Geol. Min. 2004, 115, 629-640.

75. Dominguez, M.C.; Brell Parladé, J.M.; Doval Montoya, M.; Garccía-Romero, E. Análisis de los minerales de la arcilla y sus procesos genéticos en las formaciones arcillosas de la Cuenca del Tajo. Estud. Geol. 1997, 53, 185-196. [CrossRef]

76. Pozo, M.; Casas, J.; Martín De Vidales, J.L.; Medina, J.A.; Martín Rubí, J.A. Características texturales y composicionales en depósitos de arcillas magnésicas de la Cuenca de Madrid. I) Kerolitas (sector de Esquivias y Pinto). Bol. Geol. Min. 1999, 110-111, 77-102.

77. García-Rivas, J.; Suárez, M.; Torres, T.; Sánchez-Palencia, Y.; García-Romero, E.; Ortíz, J.E. Geochemistry and Biomarker Analysis of the Bentonites from Esquivias (Toledo, Spain). Minerals 2018, 8, 291. [CrossRef]

78. De Santiago, C.; Suárez, M.; Garcia Romero, E.; Doval, M. Mg-rich smectite "precursor" phase in the Tagus Basin, Spain. Clays Clay Miner. 2000, 48, 366-373.

79. Martínez, F.J.; Julivert, M.; Sebastián, A.; Arboleda, M.L.; Gil-Ibarguchi, J.I. Structural and thermal evolution of metamorphism. In Pre-Mesozoic Geology of Iberia; Dallmeyer, R.D., Martínez García, E., Eds.; Springer: Berlin, Germany, 1988; pp. 207-211.

80. López-Moro, F.J.; López-Plaza, M. Monzonitic series from the Variscan Tormes Dome (Central Iberian Zone): Petrogenetic evolution from monzogabbro to granite magmas. Lithos 2004, 72, 19-44. [CrossRef]

81. Dias, G.; Leterrier, J.; Mendes, A.; Simões, P.P.; Bertrand, J.M. U-Pb zircon and monazite geochronology of post-collisional Hercynian granitoids from the Central Iberian Zone (Northern Portugal). Lithos 1988, 45, 349-369. [CrossRef]

82. Molina, E.; Cantano, M.; Vicente, M.A.; García Rodríguez, P. Someaspects of paleoweathering in the Iberian Hercynian Massif. Catena 1990, 17, 333-346. [CrossRef]

83. Siemcalsa. Mapa Geológico y Minero de Castilla y León: Escala 1:400.000; Siemcalsa: Valladolid, Spain, 1997.

84. Manchado, E.; Suarez, M.; Garcia Romero, E. A three-dimensional study of the kaolin deposit from Tamame de Sayago (Zamora, Spain). In Proceedings of the Euroclay 2007, Aveiro, Portugal, 22-27 July 2007; p. 73.

85. Manchado, E.M.; García-Romero, E.; Suárez, M. Génesis del Yacimiento de arcillas especiales de Tamame de Sayago (Zamora). Macla 2012, 16, 94-95.

86. Manchado, E.M. Arcillas Especiales de Tamame de Sayago (Zamora): Mineralogía, Génesis y Propiedades. Ph.D. Thesis, Universidad de Salamanca, Salamanca, Spain, 2012; p. 526.

87. Manchado, E.M.; Suárez, M.; García-Romero, E. Minerales del Grupo de la Alunita en el Yacimiento de Caolinita de Tamame de Sayago (Zamora). Macla 2008, 9, 151-152.

88. Doblas, M.; Oyarzun, R. Neogene extensional collapse in the western Mediterranean (Betic-Rif Alpine orogenic belt): Implications for the genesis of the Gibraltar Arc and magmatic activity. Geology 1989, 17, 430-433. [CrossRef]

89. Platt, J.P.; Vissers, R.L.M. Extensional collapse of thickened continental lithosphere: A working hypothesis for the Alborán Sea and Gibraltar Arc. Geology 1989, 17, 540-543. [CrossRef]

90. López Ruíz, J.; Cebriá, J.M.; Doblas, M. Cenozoic volcanism I: The Iberian Pensinsula. In The Geology of Spain; Gibbons, W., Moreno, T., Eds.; Geologiacal Society: London, UK, 2002; pp. 417-438.

91. García-Romero, E.; Suárez, M.; Oyarzun, R.; López-García, J.A.; Regueiro. Fault-hosted palygorskite from the Serrata de Nijar Deformation Zone (SE Spain). Clays Clay Miner. 2006, 54, 324-332. 
92. Huibregtse, P.; Alebeek, H.V.; Mattijs, Z.; Biermann, C. Palaeostress analysis of the northern Nijar and southern Vera basins: Constraints for the Neogene displacement history of major strike-slip faults in the Betic Cordilleras, SE Spain. Tectonophysics 1998, 300, 79-101. [CrossRef]

93. Keller, J.V.A.; Hall, S.H.; McClay, K.R. Shear fracture pattern and microstructural evolution in transpres-sional fault zones from field and laboratory studies. J. Struct. Geol. 1997, 19, 1173-1187. [CrossRef]

94. Reyes, E.; Caballero, E.; Huertas, F.; Linares, J.A. Bentonite deposits from Cabo de Gata Region, Almería, SE. Spain. Guidebook for excursions. In Proceedings of the Sixth Meeting of the European Clay Groups, Sevilla, Spain, 7-10 September 1987.

95. Linares, J.; Huertas, F.; Reyes, E.; Caballero, E.; Barahona, E.; Guardiola, J.L.; Yañez, J.; Romero, E.; Delgado, A. Investigaciones de Bentonitas Como Material de Sellado Para Almacenamiento de Residuos Radiactivos de Alta Actividad; ENRESA Thechnical Publication: Madrid, Spain, 1993; p. 324.

96. Leone, G.; Reyes, E.; Cortecci, G.; Pochini, A.; Linares, J. Genesis of bentonites from Cabo de Gata, Almería, Spain: A stable isotope study. Clay Miner. 1983, 18, 227-238. [CrossRef]

97. Caballero, E.; Reyes, E.; Linares, J.; Huertas, F. Hydrothermal solutions related to bentonite génesis, Cabo de Gata región, Almería, SE Spain. Mineral. Petrograhica Acta 1985, 29, 187-196.

98. Caballero, E.; Reyes, E.; Yusta, A.; Huertas, F.; Linares, J. Las bentonitas de la zona del Cabo de Gata, Almería. Geoquímica y mineralogía. Acta Geol. Hisp. 1985, 20, 267-287.

99. Reyes, E.; Huertas, F.; Linares, J. Bentonitas de Andalucía (España): Yacimientos hidrotermales del norte de Rodalquilar (Almería). In Proceeding of the First International Congress on Bentonites, 1978; Gallizzi: Sassari, Italy, 1978; Volume 1, pp. 125-147.

100. Reyes, E.; Huertas, F.; Linares, J. Génesis y geoquímica de esmectitas de Andalucia, España. In Proceeding of the First International Congress on Bentonites, 1978; Gallizzi: Sassari, Italy, 1978; Volume 1, pp. 149-173.

101. Delgado, A. Estudio Isotópico de los Procesos Diagenéticos e Hidrotermales Relacionados con la Génesis de Bentonitas (Cabo de Gata, Almería). Ph.D. Thesis, Universidad de Granada, Granada, Spain, 1993; p. 413.

102. Caballero, E.; Jimenez de Cisneros, C.; Huertas, F.J.; Huertas, F.; Pozzuoli, A.; Linares, J. Bentonites from Cabo de Gata, Almería, Spain: A mineralogical and geochemical overview. Clay Miner. 2005, 40, 463-480. [CrossRef]

103. Martín Vivaldi, J.L.; Linares, J. Las bentonitas de cabo de Gata. I: Yacimientos de Los Trancos y Majada de Las Vacas. Bol. Geol. Min. 1968, 79, 513-523.

104. Cuadros, J.; Delgado, A.; Cardenete, A.; Reyes, E.; Linares, J. Kaolinite/montmorillonite resembles beidellite. Clays Clay Miner. 1994, 42, 643-651. [CrossRef]

105. Pelayo, M.; García-Romero, E.; Labajo, M.A.; Pérez del Villar, L. Occurence of Fe-Mg-rich smectites and corrensite in the Morrón de Mateo bentonite deposit (Cabo de Gata region, Spain): A natural analogue of the bentonite barrier in a radwaste repository. Appl. Geochem. 2011, 26, 1135-1168. [CrossRef]

106. Di Battistini, G.; Toscani, L.; Iaccarino, S.; Villa, I.M. K/Ar ages and the geological setting of calc-alkaline volcanic rocks from Sierra de Gata. SE Spain. Neues Jahrb. Miner. Mon. 1987, 8, 369-383.

107. Fernández Soler, J.M. El Volcanismo Calco-Alcalino de Cabo de Gata (Almería). Ph.D. Thesis, Universidad de Granada, Granada, Spain, 1992; p. 243.

108. Pelayo, M.; García-Romero, E.; Labajo, M.A.; Pérez del Villar, L. Evidence of montmorillonite/Fe-rich smectite transformation in the Morrón de Mateo bentonite deposit (Spain): Implications for the clayey barrier behaviour. Appl. Clay Sci. 2016, 131, 59-70. [CrossRef]

109. Martín de Vidales, J.L.; Pozo, M.; Alia, J.M.; García Navarro, F.; Rull, R. Kerolite-stevensite mixed-layers from The Madrid Basin, Central Spain. Clay Miner. 1991, 26, 329-342. [CrossRef]

110. Göktürk, H.; Dyer, A. Sodium, rubidium and caesium uptake on Los Trancos clay. J. Radioanal. Nucl. Chem. Lett. 1994, 188, 231-241. [CrossRef]

111. Cuevas, J.; Vigil de La Villa, R.; Ramírez, S.; Petit, S.; Meunier, A.; Leguey, S. Chemistry of Mg smectites in lacustrine sediments from the Vicálvaro sepiolite deposit, Madrid Neogene basin (Spain). Clays Clay Miner. 2003, 5, 457-472. [CrossRef]

112. Newman, A.C.D.; Bown, G. Chemistry of Clays and Clay Minerals; Mineralogical Society: London, UK, 1987; p. 480.

113. Christidis, G.E. The concept of layer charge of smectites and its implications for important smectite-water properties. EMU Notes Mineral. 2011, 11, 239-260. 
114. Cuevas, J. Caracterización de Esmectitas Magnésicas de la Cuenca de Madrid Como Materiales de Sellado: Ensayos de Alteración Hidrotermal. Ph.D. Thesis, UAM, Madrid, Spain, 1990; p. 357.

115. Pozo, M.; Cuevas, J.; Moreno, A.; Redondo, R.; y Leguey, S. Caracterización de arcillas magnésicas bentoníticas en la zona de Yuncos (Toledo). Bol. Geol. Min. 1991, 102-106, 893-904.

116. Augustin, V. Estudio Geoquímico de las Alteraciones de Rocas Volcánicas en el Sector del Pozo de los Frailes, Cabo de Gata (Almería). Bachelor's Thesis, Granada University, Granada, Spain, 1973; p. 260.

117. Caballero, E. Quimismo del Proceso de Bentonitización en la Región Volcánica de Cabo de Gata (Almería). Ph.D. Thesis, Universidad de Granada, Granada, Spain, 1985; p. 198.

118. García-Romero, E.; Huertas, J. Bentonites from Cabo de Gata (Almería, Spain). Fieldtrip Guide. In Proceedings of 16th International Clay Conference; Sociedad Española de Arcillas (SEA): Granada, Spain, 17- July 2017; p. 36.

119. Caballero, E.; Fernandez Porto, M.J.; Linares, J.; Huertas, F.; Reyes, E. Las bentonitas de la Serrata de Nijar (Almería): Mineralogía, geoquímica y mineralogénesis. Estud. Geol. 1983, 39, 121-140.

(C) 2019 by the authors. Licensee MDPI, Basel, Switzerland. This article is an open access article distributed under the terms and conditions of the Creative Commons Attribution (CC BY) license (http://creativecommons.org/licenses/by/4.0/). 